\title{
AROMATIC PLANTS IN WEED CONTROL: INFLUENCE ON THE BROMUS ANTIOXIDANT SYSTEM AND SOIL MICROORGANISM GROWTH
}

\author{
ŠUĆUR, J. ${ }^{1}$ - PRVUlović, D. ${ }^{1}$ - MAlenČIĆ, D. J. ${ }^{1}$ - DJuRIĆ, S. ${ }^{1}$ - MANOJLOVIĆ, A. ${ }^{1}$ - \\ ANAČKOV, G. $^{2}-$ POPOV, M. $^{1}-$ KONSTANTINOVIĆ, B..$^{1 *}$ \\ ${ }^{1}$ Faculty of Agriculture, University of Novi Sad, Trg Dositeja Obradovića 8, Novi Sad, Serbia \\ ${ }^{2}$ Faculty of Science, University of Novi Sad, Trg Dositeja Obradovića 3, Novi Sad, Serbia \\ *Corresponding author \\ e-mail:bojank@polj.uns.ac.rs; phone: +381-21-485-3315
}

(Received 26 $6^{\text {th }}$ Oct 2018; accepted $7^{\text {th }}$ Jan 2019)

\begin{abstract}
Natural compounds produced in plant metabolism can offer an alternative method to the chemical control of weeds. The aim of this study was to evaluate the effects of Salvia sclarea L. and Clinopodium menthifolium Host on the bromus (Bromush mollish L.) antioxidant properties to explore the potential of these aromatic plants in weed control. The impact of bioherbicides on the growth of beneficial microorganism present in the soil is less known. Consequently, the second aim was to evaluate the effects of $S$. sclarea and C. menthifolium on the growth of beneficial microorganism so as to assess theirs possible side effects when applied as bioherbicides. Two different concentrations $(0.1 \%$ and $0.2 \%)$ of the aqueous extract of $S$. sclarea and C. menthifolium were assayed. Both tested extracts caused a change in peroxidase (POD) activity in leaves and roots of the bromus plants. Furthermore, both extracts induced lipid peroxidation in bromus leaves. In addition, tested extracts showed positive effects on the growth of some beneficial bacteria. The results indicate that $S$. sclarea and $C$. menthifolium aqueous extracts have negative effects on the antioxidant system in bromus plants with no inhibitory effects on the growth of the beneficial mycorrhizal bacteria and fungi.
\end{abstract}

Keywords: allelochemicals, beneficial bacteria, bioherbicides, Bromush mollish L., enzyme activity

\section{Introduction}

Throughout the years, the separation, characterization and production of natural products have been used as pesticides against insects, weeds, plant pathogens, and nematodes in the field. In the context of green chemistry (Abd El-Gawad, 2016), there is an urgent need for development of natural products called biopesticides as an alternative for maintaining high production with low ecological impact (Hermosa et al., 2012). Weeds have been documented as serious plant pests which constantly compete with crops for light and nutrients which cause considerable losses in their productivity (Jabran et al., 2015). Therefore, nitrogen $(\mathrm{N})$, phosphorus $(\mathrm{P})$, and potassium $(\mathrm{K})$ uptake is reduced (Gonzalez Ponce et al., 1996). One of the highly resistant weed species in our crops is bromus.

With the constant implementation of synthetic herbicides in crop protection systems weeds have developed resistance. Herbicide resistance demands a new solution to cope with economic losses generated by weeds (Abd El-Gawad, 2016). Allelopathy is an ecological phenomenon where plants produce a great variety of secondary metabolites, called allelochemicals (Abd El-Gawad, 2016; Céspedes et al., 2014). These compounds belong to numerous chemical groups including: phenolic acids, flavonoids, triketones, terpenes, benzoquinones, coumarins, terpenoids, tannins lignin, fatty acids and nonprotein amino acids (Soltys et al., 2013). They are important in mediating interactions 
between plants and their biotic environment (Céspedes et al., 2014). Allelochemicals either have an inhibitory or stimulatory effect on plants, and they are considered to be a natural defense mechanism of plants (Abd El-Gawad, 2016).

Allelochemicals may be synthesised in all plant organs like leaves, stems, flowers, fruits, seeds and roots (Farooq et al., 2011). One of the main invisible effects of allelochemicals on the target plant is uncontrolled production of reactive oxygen species (ROS) (Bogatek et al., 2006). Under stress conditions, the generation of ROS is greatly increased (Soares et al., 2016). ROS are highly reactive and in the absence of any protective mechanism, they can seriously damage vital biomolecules such as lipids, proteins and nucleic acids (Meloni and Martinez, 2009). To mitigate the oxidative damage induced by ROS, plants have developed antioxidant defense systems, enzymatic and nonenzymatic (Azevedo Neto et al., 2006). During oxidative stress, plants produce hydrogen peroxide which is considered harmful to plant cells (Šimonovičová et al., 2004). Peroxidases are one of the major $\mathrm{H}_{2} \mathrm{O}_{2}$-scavenging enzymes. The cellular level of $\mathrm{H}_{2} \mathrm{O}_{2}$ could be toxic enough to inhibit the enzymes' activity, leaving the plant vulnerable to oxidative damage (Mandal et al., 2013). Allelopathic interactions between plants may become an alternative to pesticides for weed control (Khalid et al., 2002).

Salvia sclarea, commonly called clary sage, and Clinopodium menthifolium belong to Lamiaceae. S. sclarea is an important medicinal herb (Kumar and Sharma, 2012). The major phytochemicals of the sage plant are phenols and terpenoids. Different bioassays of plant extracts have shown biological activities such as antimicrobial, antioxidant, cytotoxic, antiprotozoal, antidiabetic (Mahmood et al., 2012). The aqueous extract of aromatic plants, which is rich in phenols, is easily used for foliar application due to their rich water solubility and their ability to create a uniform spray mixture.

The major objective of this study was to evaluate the allelopathic effects of the aqueous extract of two aromatic plants, Salvia sclarea L. and Clinopodium menthifolium Host, on bromus (Bromush mollish L.) antioxidant properties to explore the potential of this species in weed control. The effect of the two concentrations $(0.1$ and $0.2 \%)$ of $S$. sclarea and $C$. menthifolium aqueous extracts on the lipid peroxidation process (LP), as well as the activity of peroxidase (POD) antioxidant enzymes (pyrogallol and guaiacol peroxidases) in leaves and roots of bromus seedlings were examined 24, 72 and $120 \mathrm{~h}$ after the treatment. Due to strong antimicrobial activity of aromatic plants, the impact of tested aqueous extracts on the growth of beneficial microorganism present in the soil was additionally investigated.

\section{Materials and methods}

\section{Plant materials and preparation of the aqueous extracts}

Salvia sclarea L. was collected in the south of Serbia, around Vranje town (longitude: 21 ${ }^{\circ} 53$ '09.23” E, latitude: 42 22'40.44” N, altitude: $494 \mathrm{~m}$ ), in July of 2012. Clinopodium menthifolium (Host) was collected at localities near the Adriatic coast in Montenegro, around Sutomore town and Čanj town (longitude: $19^{\circ} 00^{\prime} 30.10^{\prime \prime}$ E, latitude: 42 $09^{\prime} 52.19^{\prime \prime}$ N, altitude: $31 \mathrm{~m}$ ), in May of 2012. Voucher specimens Salvia sclarea L. N 2-1545 and Clinopodium menthifolium (Host) $\mathrm{N}^{\circ} 2-1543$ were confirmed and deposited at the Herbarium of The Department of Biology and Ecology, Faculty of Science, University of Novi Sad (Holmgren and Holmgren, 2003).

The plants were dried at $30{ }^{\circ} \mathrm{C}$ for two weeks, and the dried plants were then ground into powder. The powdery material $(10 \mathrm{~g})$ was spilled with $100 \mathrm{~mL}$ of boiling distilled 
water $(10 \%, w / v)$ and left for $24 \mathrm{~h}$. After $24 \mathrm{~h}$, the extracts were filtered through Whatman No. 4 filter paper and kept at $4{ }^{\circ} \mathrm{C}$ in the fridge until application.

\section{Seedling growth}

The experiment was performed at the Laboratory of Biochemistry, Faculty of Agriculture, Novi Sad and conducted under controlled conditions $\left(28{ }^{\circ} \mathrm{C}, 60 \%\right.$ relative humidity, a photoperiod of $18 \mathrm{~h}$, and a light intensity of $10.000 \mathrm{~lx}$ ). The bromus (Bromus mollish L.) seeds were surface-sterilized with $3 \% \mathrm{H}_{2} \mathrm{O}_{2}(\mathrm{v} / \mathrm{v})$, washed with deionised water, placed in plastic pots containing sterile sand and maintained under dark conditions. Thirty-day-old seedlings were transplanted in plastic pots containing $700 \mathrm{~mL}$ of Hoagland's solution prepared according to Hoagland and Arnon (1950), and 7 or $14 \mathrm{~mL}$ of $10 \% \mathrm{~S}$. sclarea and C. menthifolium aqueous extract, separately, while pots of control contained the same volume of nutrient solution. When $7 \mathrm{~mL}$ of the plant extract was added to the solution, the final concentration of the extract was $0.1 \%$. When $14 \mathrm{~mL}$ of the plant extract was added to the solution, the final concentration of the extract was $0.2 \%$. The bromus plants were harvested for determining the investigated biochemical parameters 24,72 and $120 \mathrm{~h}$ after the treatments with the plant aqueous extracts.

\section{Analysis of the POD antioxidant enzymes and MDA content}

For the determination of the peroxidase (POD) activity and malondialdehyde (MDA) content, $2 \mathrm{~g}$ of fresh plant material (bromus leaves and roots from each growth condition: control, 0.1 and $0.2 \%$ plant aqueous extracts) was homogenized in $10 \mathrm{~mL}$ of phosphate buffer (0.1 M, pH 7.0) prepared in-house. After centrifugation, supernatants (bromus extracts) were used for protein quantification and POD activity assays. Biochemical analyses were carried out spectrophotometrically using an UV/VIS spectrophotometer (Thermo Scientific Evolution 220 (USA)). A measurement of protein levels in the supernatants was performed according to the method of Bradford (Sedmark and Grossberg, 1977; Spector, 1978). The activity of the POD (EC 1.11.1.7) was measured using guaiacol and pyrogallol as substrates according to Morkunas and Gmerek (2007). The absorbance was recorded at $436 \mathrm{~nm}$. The activity of the POD was expressed in U/mg of proteins. The MDA content, an end product of lipid peroxidation process, was measured at $532 \mathrm{~nm}$ using the thiobarbituric acid (TBA) test (Mandal et al., 2008). The total amount of TBA-reactive substances was given in nmol of MDA equivalents/mg of proteins.

\section{Bacteria culture}

The test microorganism used in this study were as follows: Azotobacter-isolates 1 and 2; Pseudomonas-isolates 1, 2, and Marker; Bacillus-Bacillus subtilis marker 44, Bacillus subtilis and Bacillus megaterium; Rhizobium-isolate $\mathrm{D}_{1}$, Bradyrhizobium japonicum isolate S511, Rhizobium trifolii 1; fungi-Penicillium sp., Alternarium sp. and Trichoderma asperellum. The collection of microbial soil isolates is from the Laboratory of Microbiology, Faculty of Agriculture, University of Novi Sad, Serbia).

\section{Microorganism cultivation}

Azotobacter isolates were grown on mannitol selective nutrient medium (mannitol $20.0 \mathrm{~g}, \mathrm{~K}_{2} \mathrm{HPO}_{4} 0.3 \mathrm{~g}, \mathrm{CaHPO}_{4} 0.2 \mathrm{~g}, \mathrm{MgSO}_{4} 0.3 \mathrm{~g}, \mathrm{NaCl} 0.5 \mathrm{~g}, \mathrm{FeCl}_{3} 0.1 \mathrm{~g}, \mathrm{CaCO}_{3}$ 
$2.5 \mathrm{~g}$, microelements solution $1.0 \mathrm{~mL}$, distilled $\mathrm{H}_{2} \mathrm{O} 1000.0 \mathrm{~mL}, \mathrm{pH}$ 8.2) for $48 \mathrm{~h}$ on $150 \mathrm{rpm}$ at $28{ }^{\circ} \mathrm{C}$ in shaker incubator (Aquilanti et al., 2004). After OD determination on $600 \mathrm{~nm}$ all inocula were adjusted at $10^{8}$ cell $\mathrm{mL}^{-1}$. Pseudomonas isolates were grown on King - B nutritet medium (pepton 10.0 g, trypton 10.0 g, $\mathrm{K}_{2} \mathrm{HPO}_{4} 1.5 \mathrm{~g}, \mathrm{MgSO}_{4} 1.5 \mathrm{~g}$, glycerol $10.0 \mathrm{~mL}$, distilled $\mathrm{H}_{2} \mathrm{O} 1000.0 \mathrm{~mL}, \mathrm{pH} \mathrm{7.2)} \mathrm{for} 48 \mathrm{~h}$ on $150 \mathrm{rpm}$ at $28{ }^{\circ} \mathrm{C}$ in shaker incubator (Valls et al., 1999). After OD determination on $600 \mathrm{~nm}$ all inocula were adjusted at $10^{8}$ cell $\mathrm{mL}^{-1}$. Bacillus subtils and Bacillus megaterium strains were grown on the $\mathrm{L}$ - agar, selective liqud nutrient medium (distilled $\mathrm{H}_{2} \mathrm{O} 1000 \mathrm{~mL}$, tripton $10.0 \mathrm{~g}$, yeast extract $5.0 \mathrm{~g}, \mathrm{NaCl} 5.0 \mathrm{~g}$,) for $48 \mathrm{~h}$ on $150 \mathrm{rpm}$ at $28{ }^{\circ} \mathrm{C}$ in shaker incubator (Valls et al., 1999). After OD determination on $600 \mathrm{~nm}$ all inocula were adjusted at $10^{8}$ cell $\mathrm{mL}^{-1}$. Bradyrhizobium japonicum isolate $\mathrm{S} 511$ and Rhizobium isolates were grown on YMB selective liqude medium (mannitol $10.0 \mathrm{~g}$, yeast extract $0.5 \mathrm{~g}, \mathrm{~K}_{2} \mathrm{HPO}_{4} 0.5 \mathrm{~g}, \mathrm{KH}_{2} \mathrm{PO}_{4}$ $0.5 \mathrm{~g}, \mathrm{MgSO}_{4} 0.2 \mathrm{~g}, \mathrm{NaCl} 0.1 \mathrm{~g}$ distilled $\mathrm{H}_{2} \mathrm{O} 1000.0 \mathrm{~mL}, \mathrm{pH}$ 7.2), B japonicum for 5 days and Rhizobium sp. for 3 days on $150 \mathrm{rpm}$ at $28{ }^{\circ} \mathrm{C}$ in shaker incubator. After OD determination on $600 \mathrm{~nm}$ all inocula were adjusted at $10^{8}$ cell $\mathrm{mL}^{-1}$.

Pure cultures of fungi - Trichoderma asperellum, Penicillium sp., and Alternarium sp. were isolated from serial dilutions and grown on potato dextrose agar (PDA, Difco ${ }^{\circledR}$ ) at $25 \pm 1{ }^{\circ} \mathrm{C}$ for at least 7 days. Single colonies were purified by re-isolation on PDA and a single hyphal tip was isolated and grown on PDA. The sporulated colony arising from this hyphal tip was used to make inocula with $10^{6}$ spore $\mathrm{mL}^{-1}$ for each fungi.

\section{Disc diffusion method}

The evaluation of the $S$. sclarea and $C$. menthifolium aqueous extracts on the growth of microorganism was carried out by the disc diffusion method described by Prabuseenivasan et al. (2006). Sterilized Petri dishes with agar were inoculated with microorganism cultures. The paper discs impregnated with plant aqueous extracts were placed on the agar surface. The plates were incubated at $28^{\circ} \mathrm{C}$. After incubation $(72 \mathrm{~h}$ and $120 \mathrm{~h}$ ), the plates were examined for the stimulation/inhibition zone (Fig. 1). The test was repeated three times to ensure reliability.
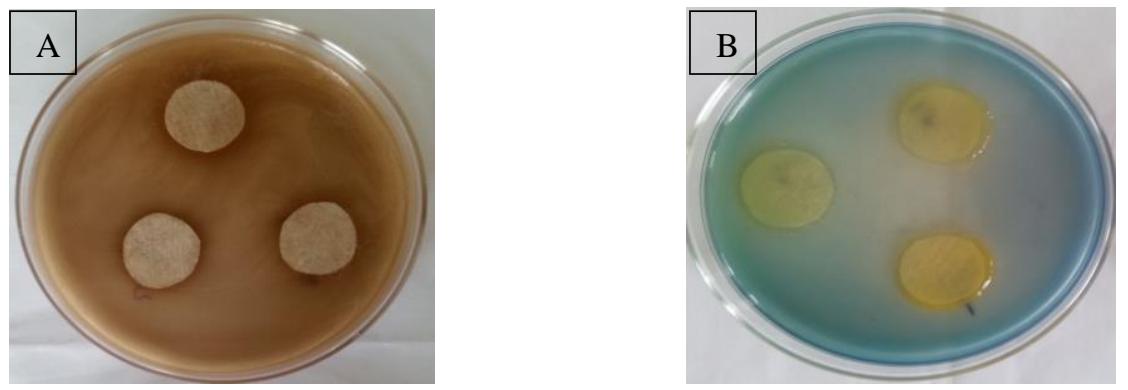

Figure 1. The bacterial strain growth stimulator zone Azotobacter isolate 1 (A) and Bradyrhizobium japonicum isolate S511 (B) under the influence of the S. sclarea aqueous extract

\section{Statistical analysis}

All measurements were performed in triplicates. Values of the biochemical parameters were expressed as mean \pm standard error of mean and tested by ANOVA followed by comparison of the means by Duncan's multiple range test $(\mathrm{P}<0.05)$. Data were analyzed 
using STATISTICA for Windows version 11.0. Comparable percentage was done by Equation 1.

$$
\Delta(\%)=(100 \times \text { sample } / \text { control })-100
$$

\section{Results \\ $P O D$ activity and MDA content in bromus leaves and roots}

In leaves of the bromus plants, a significant decrease in activity of POD was detected $72 \mathrm{~h}$ after the treatment with $0.1 \%$ S. sclarea aqueous extract (Fig 2). The activity of pyrogallol peroxidase showed a $30 \%$ decrease, while the activity of guaiacol peroxidase showed a $36 \%$ decrease (Table 1). In the treatment with a higher concentration of the $S$. sclarea aqueous extract $(0.2 \%)$, there were no significant differences in the activity of POD in the leaves of treated bromus plants compared to plants from the control group. On the other hand, in the roots of bromus, a lower tested concentration of S. sclarea aqueous extract $(0.1 \%)$ significantly increased the activity of POD $120 \mathrm{~h}$ after the treatment. The activity of pyrogallol and guaiacol peroxidases was increased by $117 \%$ and $248 \%$, respectively. In the treatment with a higher concentration $(0.2 \%)$ a significant increase in the activity of pyrogallol peroxidase was detected $72 \mathrm{~h}$ after the treatment $(98 \%)$.

Table 1. The effect of the two concentrations (0.1 and 0.2\%) of the S. sclarea aqueous extract on the activities of the antioxidant enzymes (U/mg protein) and on MDA content (nmol/mg protein) in leaves and roots of the bromus seedlings compared to the control group

\begin{tabular}{|c|c|c|c|c|}
\hline \multicolumn{2}{|c|}{ Time } & $24 \mathrm{~h}$ & $72 \mathrm{~h}$ & $120 \mathrm{~h}$ \\
\hline \multicolumn{5}{|c|}{ Leaves } \\
\hline \multirow{3}{*}{$\begin{array}{c}\text { Guaiacol } \\
\text { peroxidase }\end{array}$} & Control & $(4.01 \pm 0.09) \cdot 10^{2 \mathrm{a}}$ & $(3.56 \pm 0.32) \cdot 10^{2 \mathrm{a}}$ & $(5.17 \pm 0.18) \cdot 10^{2 b}$ \\
\hline & $0.1 \%$ & $(4.77 \pm 0.27) \cdot 10^{2 b}$ & $(2.29 \pm 0.17) \cdot 10^{2 \mathrm{c}}$ & $(3.74 \pm 0.13) \cdot 10^{2 \mathrm{a}}$ \\
\hline & $0.2 \%$ & $(3.44 \pm 0.04) \cdot 10^{2 \mathrm{a}}$ & $(5.46 \pm 0.25) \cdot 10^{2 b}$ & $(5.05 \pm 0.41) \cdot 10^{2 b}$ \\
\hline \multirow{3}{*}{$\begin{array}{l}\text { Pyrogallol } \\
\text { peroxidase }\end{array}$} & Control & $(3.87 \pm 0.18) \cdot 10^{2 \mathrm{a}}$ & $(3.51 \pm 0.10) \cdot 10^{2 \mathrm{a}}$ & $(3.41 \pm 0.37) \cdot 10^{2 \mathrm{a}}$ \\
\hline & $0.1 \%$ & $(3.35 \pm 0.39) \cdot 10^{2 \mathrm{a}, \mathrm{b}}$ & $(2.48 \pm 0.14) \cdot 10^{2 b}$ & $(3.35 \pm 0.98) \cdot 10^{2 \mathrm{a}, \mathrm{b}}$ \\
\hline & $0.2 \%$ & $(3.63 \pm 0.31) \cdot 10^{2 \mathrm{a}}$ & $(3.21 \pm 0.33) \cdot 10^{2 \mathrm{a}, \mathrm{b}}$ & $(3.40 \pm 0.34) \cdot 10^{2 \mathrm{a}}$ \\
\hline \multirow{3}{*}{ MDA content } & Control & $3.83 \pm 0.02^{\mathrm{a}, \mathrm{b}}$ & $3.26 \pm 0.15^{\mathrm{c}}$ & $5.48 \pm 0.07^{\mathrm{f}}$ \\
\hline & $0.1 \%$ & $4.87 \pm 0.05^{\mathrm{e}}$ & $4.44 \pm 0.03^{d}$ & $3.60 \pm 0.05^{\mathrm{a}}$ \\
\hline & $0.2 \%$ & $3.70 \pm 0.10^{\mathrm{a}}$ & $4.00 \pm 0.03^{b}$ & $7.04 \pm 0.09^{\mathrm{g}}$ \\
\hline \multicolumn{5}{|c|}{ Roots } \\
\hline \multirow{3}{*}{$\begin{array}{c}\text { Guaiacol } \\
\text { peroxidase }\end{array}$} & Control & $(2.09 \pm 0.21) \cdot 10^{3 \mathrm{a}, \mathrm{b}}$ & $(1.56 \pm 0.05) \cdot 10^{3 \mathrm{a}}$ & $(1.03 \pm 0.00) \cdot 10^{3 \mathrm{c}}$ \\
\hline & $0.1 \%$ & $(1.71 \pm 0.12) \cdot 10^{3 \mathrm{a}}$ & $(0.59 \pm 0.02) \cdot 10^{3 \mathrm{c}}$ & $(3.59 \pm 0.17) \cdot 10^{3 \mathrm{~d}}$ \\
\hline & $0.2 \%$ & $(2.53 \pm 0.26) \cdot 10^{3 b}$ & $(2.04 \pm 0.16) \cdot 10^{3 \mathrm{a}}$ & $(1.68 \pm 0.08) \cdot 10^{3 \mathrm{a}}$ \\
\hline \multirow{3}{*}{$\begin{array}{l}\text { Pyrogallol } \\
\text { peroxidase }\end{array}$} & Control & $(1.75 \pm 0.02) \cdot 10^{3 \mathrm{a}}$ & $(0.53 \pm 0.02) \cdot 10^{3 \mathrm{c}}$ & $(0.94 \pm 0.16) \cdot 10^{3 \mathrm{~b}, \mathrm{c}}$ \\
\hline & $0.1 \%$ & $(1.27 \pm 0.04) \cdot 10^{3 \mathrm{~b}}$ & $(0.47 \pm 0.01) \cdot 10^{3 \mathrm{c}}$ & $(2.04 \pm 0.10) \cdot 10^{3 \mathrm{a}}$ \\
\hline & $0.2 \%$ & $(1.99 \pm 0.11) \cdot 10^{3 \mathrm{a}}$ & $(1.05 \pm 0.32) \cdot 10^{3 \mathrm{~b}}$ & $(0.97 \pm 0.23) \cdot 10^{3 \mathrm{~b}, \mathrm{c}}$ \\
\hline \multirow{3}{*}{ MDA content } & Control & $1.66 \pm 0.16^{\mathrm{a}, \mathrm{b}}$ & $1.52 \pm 0.13^{\mathrm{a}}$ & $2.85 \pm 1.36^{\mathrm{a}, \mathrm{b}}$ \\
\hline & $0.1 \%$ & $2.64 \pm 0.10^{\mathrm{a}, \mathrm{b}}$ & $1.93 \pm 0.08^{\mathrm{a}, \mathrm{b}}$ & $2.46 \pm 0.01^{\mathrm{a}, \mathrm{b}}$ \\
\hline & $0.2 \%$ & $3.22 \pm 0.08^{\mathrm{b}}$ & $2.36 \pm 0.10^{\mathrm{a}, \mathrm{b}}$ & $2.16 \pm 0.04^{\mathrm{a}, \mathrm{b}}$ \\
\hline
\end{tabular}

The data are mean values \pm standard error

${ }^{\text {a-f }}$ Values without the same superscripts within each column differ significantly $(P<0.05)$ 
In the treatment with $0.1 \% \quad C$. menthifolium aqueous extract, there were no significant differences in the activity of pyrogallol peroxidase in the leaves of bromus between the plants from the control group and the treatments (Table 2). In the treatment with a higher concentration of the $C$. menthifolium aqueous extract $(0.2 \%)$, a significant increase in the activity of pyrogallol peroxidase was detected $120 \mathrm{~h}$ after the treatment $(26 \%)$. A significant increase in the activity of guaiacol peroxidase was detected in the leaves of bromus $72 \mathrm{~h}$ after the treatment. The activity of guaiacol peroxidase showed an increase of $88 \%$ in the treatment with $0.1 \%$ C. menthifolium aqueous extract and an increase of $85 \%$ in the treatment with $0.2 \%$ C. menthifolium aqueous extract. In the roots of bromus plants, both tested concentrations of $C$. menthifolium aqueous extract decreased the activity of pyrogallol and guaiacol peroxidases. In the treatment with a higher concentration $(0.2 \%)$, a significant decrease in the activity of guaiacol peroxidase was detected $(71 \% 24 \mathrm{~h}$ after the treatment, $75 \% 72 \mathrm{~h}$ after the treatment, and $55 \%$ $120 \mathrm{~h}$ after the treatment). In the treatment with $0.1 \%$ C. menthifolium aqueous extract, a significant decrease in the activity of guaiacol peroxidase was detected as well $(52 \%$ $24 \mathrm{~h}$ after the treatment, $67 \% 72 \mathrm{~h}$ after the treatment, and $51 \% 120 \mathrm{~h}$ after the treatment). The activity of pyrogallol peroxidase showed a decrease of $48 \%$ in the treatment with $0.1 \%$ and a decrease of $68.5 \%$ in the treatment with $0.2 \% \quad C$. menthifolium aqueous extract $120 \mathrm{~h}$ after the treatment.

Table 2. The effect of the two concentrations (0.1 and 0.2\%) of the C. menthifolium aqueous extract on the activities of the antioxidant enzymes (U/mg protein) and on MDA content (nmol/mg protein) in leaves and roots of the bromus seedlings compared to the control group

\begin{tabular}{|c|c|c|c|c|}
\hline \multicolumn{2}{|c|}{ Time } & $24 \mathrm{~h}$ & $72 \mathrm{~h}$ & $120 \mathrm{~h}$ \\
\hline \multicolumn{5}{|c|}{ Leaves } \\
\hline \multirow{3}{*}{$\begin{array}{c}\text { Guaiacol } \\
\text { peroxidase }\end{array}$} & Control & $(4.01 \pm 0.09) \cdot 10^{2 \mathrm{a}, \mathrm{c}}$ & $(3.56 \pm 0.32) \cdot 10^{2 c}$ & $(5.17 \pm 0.18) \cdot 10^{2 \mathrm{a}, \mathrm{b}, \mathrm{c}}$ \\
\hline & $0.1 \%$ & $(5.60 \pm 0.33) \cdot 10^{2 a, b}$ & $(6.69 \pm 0.51) \cdot 10^{2 b}$ & $(5.56 \pm 1.17) \cdot 10^{2 \mathrm{a}, \mathrm{b}}$ \\
\hline & $0.2 \%$ & $(4.06 \pm 0.17) \cdot 10^{2 \mathrm{a}, \mathrm{c}}$ & $(6.59 \pm 0.43) \cdot 10^{2 b}$ & $(4.14 \pm 0.42) \cdot 10^{2 \mathrm{a}}$ \\
\hline \multirow{3}{*}{$\begin{array}{l}\text { Pyrogallol } \\
\text { peroxidase }\end{array}$} & Control & $(3.87 \pm 0.18) \cdot 10^{2 a, b}$ & $(3.51 \pm 0.10) \cdot 10^{2 \mathrm{a}, \mathrm{b}, \mathrm{c}}$ & $(3.41 \pm 0.37) \cdot 10^{2 \mathrm{a}, \mathrm{c}}$ \\
\hline & $0.1 \%$ & $(4.14 \pm 0.16) \cdot 10^{2 a, b}$ & $(4.37 \pm 0.36) \cdot 10^{2 b}$ & $(3.38 \pm 0.18) \cdot 10^{2 \mathrm{a}}$ \\
\hline & $0.2 \%$ & $(2.92 \pm 0.21) \cdot 10^{2 \mathrm{c}}$ & $(4.01 \pm 0.26) \cdot 10^{2 a, b}$ & $(4.30 \pm 0.24) \cdot 10^{2 \mathrm{~b}}$ \\
\hline \multirow{3}{*}{$\begin{array}{l}\text { MDA } \\
\text { content }\end{array}$} & Control & $3.83 \pm 0.02^{\mathrm{a}}$ & $3.26 \pm 0.15^{\mathrm{c}}$ & $5.48 \pm 0.07^{\mathrm{e}}$ \\
\hline & $0.1 \%$ & $3.98 \pm 0.07^{\mathrm{a}, \mathrm{b}}$ & $4.76 \pm 0.04^{\mathrm{d}}$ & $4.24 \pm 0.07^{\mathrm{b}}$ \\
\hline & $0.2 \%$ & $4.22 \pm 0.13^{\mathrm{b}}$ & $4.83 \pm 0.15^{\mathrm{d}}$ & $5.45 \pm 0.09^{\mathrm{e}}$ \\
\hline \multicolumn{5}{|c|}{ Roots } \\
\hline \multirow{3}{*}{$\begin{array}{l}\text { Guaiacol } \\
\text { peroxidase }\end{array}$} & Control & $(20.96 \pm 2.15) \cdot 10^{2 \mathrm{a}}$ & $(15.69 \pm 0.51) \cdot 10^{2 b}$ & $(10.31 \pm 0.40) \cdot 10^{2 b}$ \\
\hline & $0.1 \%$ & $(10.11 \pm 0.27) \cdot 10^{2 b}$ & $(5.18 \pm 0.49) \cdot 10^{2 \mathrm{c}}$ & $(5.31 \pm 0.08) \cdot 10^{2 \mathrm{c}}$ \\
\hline & $0.2 \%$ & $(6.20 \pm 0.82) \cdot 10^{2 \mathrm{c}}$ & $(3.95 \pm 0.23) \cdot 10^{2 \mathrm{c}}$ & $(4.63 \pm 0.71) \cdot 10^{2 \mathrm{c}}$ \\
\hline \multirow{3}{*}{$\begin{array}{l}\text { Pyrogallol } \\
\text { peroxidase }\end{array}$} & Control & $(17.51 \pm 0.28) \cdot 10^{2 \mathrm{a}}$ & $(5.36 \pm 0.24) \cdot 10^{2 \mathrm{c}, \mathrm{d}}$ & $(9.47 \pm 1.60) \cdot 10^{2 b}$ \\
\hline & $0.1 \%$ & $(10.70 \pm 0.42) \cdot 10^{2 b}$ & $(7.17 \pm 0.48) \cdot 10^{2 \mathrm{c}}$ & $(4.91 \pm 0.43) \cdot 10^{2 \mathrm{e}}$ \\
\hline & $0.2 \%$ & $(10.28 \pm 0.57) \cdot 10^{2 b}$ & $(5.03 \pm 0.15) \cdot 10^{2 \mathrm{~d}}$ & $(2.98 \pm 0.27) \cdot 10^{2 \mathrm{~b}, \mathrm{c}}$ \\
\hline \multirow{3}{*}{$\begin{array}{l}\text { MDA } \\
\text { content }\end{array}$} & Control & $1.66 \pm 0.16^{\mathrm{a}}$ & $1.52 \pm 0.13^{\mathrm{a}}$ & $2.85 \pm 1.36^{\mathrm{a}}$ \\
\hline & $0.1 \%$ & $1.72 \pm 0.02^{\mathrm{a}}$ & $1.73 \pm 0.01^{\mathrm{a}}$ & $1.79 \pm 0.04^{\mathrm{a}}$ \\
\hline & $0.2 \%$ & $1.72 \pm 0.22^{\mathrm{a}}$ & $1.56 \pm 0.01^{\mathrm{a}}$ & $1.55 \pm 0.04^{\mathrm{a}}$ \\
\hline
\end{tabular}

The data are mean values \pm standard error

${ }^{\mathrm{a}-\mathrm{e}}$ Values without the same superscripts within each column differ significantly $(P<0.05)$ 


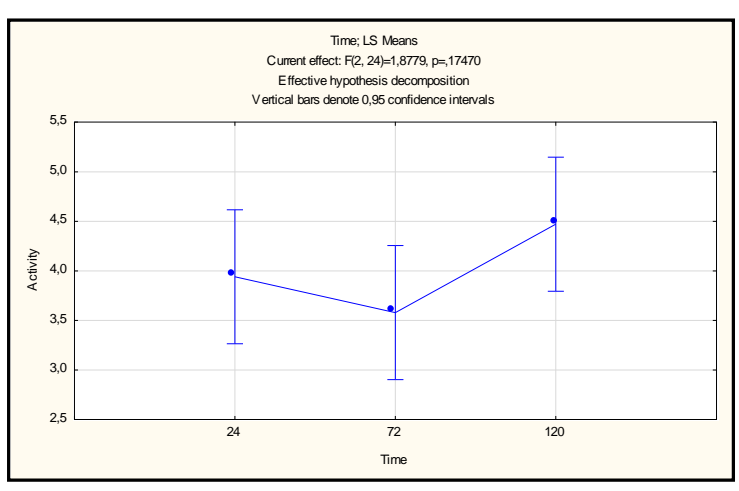

A

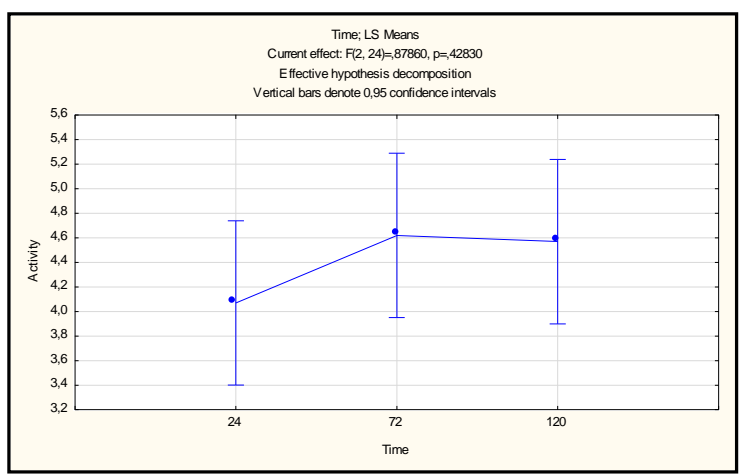

C

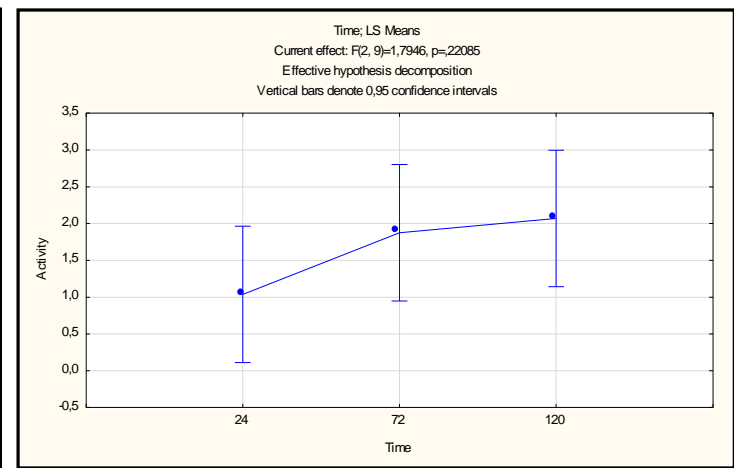

B

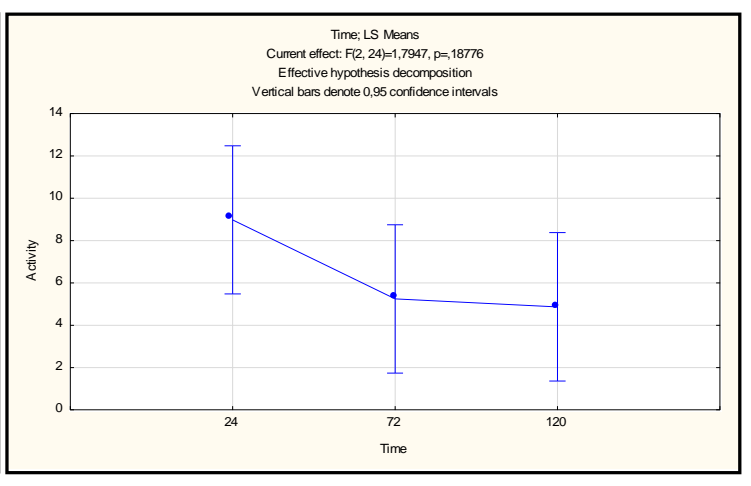

D

Figure 2. The relationship between the period of time and the activities of the antioxidant enzymes in leaves of the bromus treated with $S$. sclarea aqueous extract (A), roots of the bromus treated with $S$. sclarea aqueous extract $(B)$, leaves of the bromus treated with $C$. menthifolium aqueous extract $(C)$, roots of the bromus treated with $C$. menthifolium aqueous extract $(D)$

The accumulation of malondialdehyde (MDA), an end product of the lipid peroxidation process, was significantly higher in leaves of bromus plants $120 \mathrm{~h}$ after the treatment with $S$. sclarea extract and $72 \mathrm{~h}$ after the treatment with $C$. menthifolium extract (Fig. 3). In the treatment with $0.2 \%$ S. sclarea aqueous extract, the accumulation of MDA was $29 \%$ (Table 1). In the treatment with $0.1 \%$ and $0.2 \%$ C. menthifolium aqueous extract the accumulation of MDA was $46 \%$ and $48 \%$, respectively (Table 2). Furthermore, the accumulation of MDA was higher in leaves of bromus plants after the treatment with $C$. menthifolium aqueous extract compared to $S$. sclarea aqueous extract. This observation could indicate that $C$. menthifolium possesses a higher phytotoxic effect than $S$. sclarea. On the other hand, in the roots of bromus plants, there was no significant increase in the lipid peroxidation intensity.

\section{Disc diffusion method}

In the treatment with both concentrations $(0.1 \%$ and $0.2 \%)$ of $S$. sclarea and $C$. menthofolium aqueous extracts, separately, there were no stimulatory or inhibitory effects on the growth of the bacteria Pseudomonas - isolates 1, 2, and Marker; Bacillus - Bacillus subtilis and Bacillus megaterium; Rhizobium trifolii 1; and fungi - Penicillium sp., Alternarium sp. and Trichoderma asperellum. 
The tested extracts showed a stimulatory effect on the growth of the Azotobacter - isolates 1 and 2; Bacillus subtilis marker 44, Rhizobium isolate $\mathrm{D}_{1}$, Bradyrhizobium japonicum isolate S511 $120 \mathrm{~h}$ after the treatment with the zone of stimulation ranging from 2 to $8 \mathrm{~mm}$ (Figs. 4 and 5).

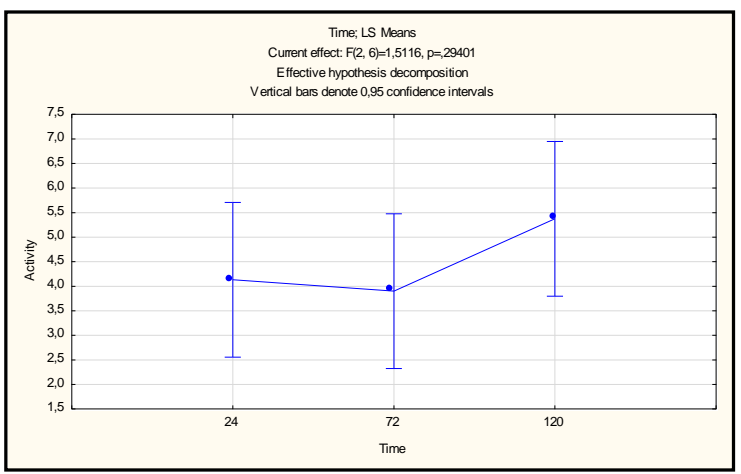

A

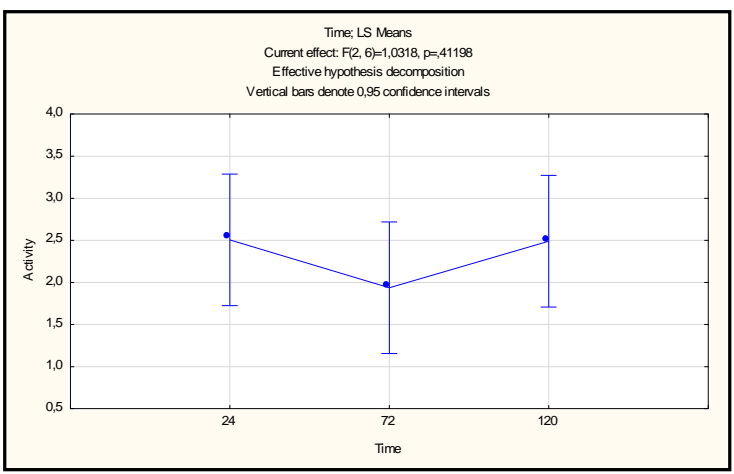

B

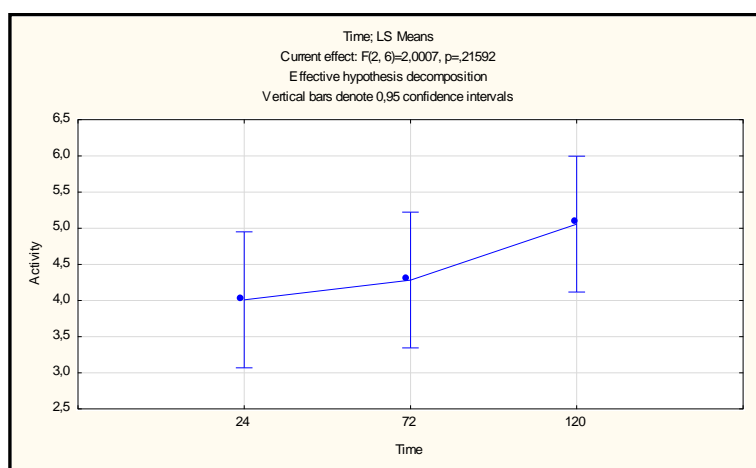

C

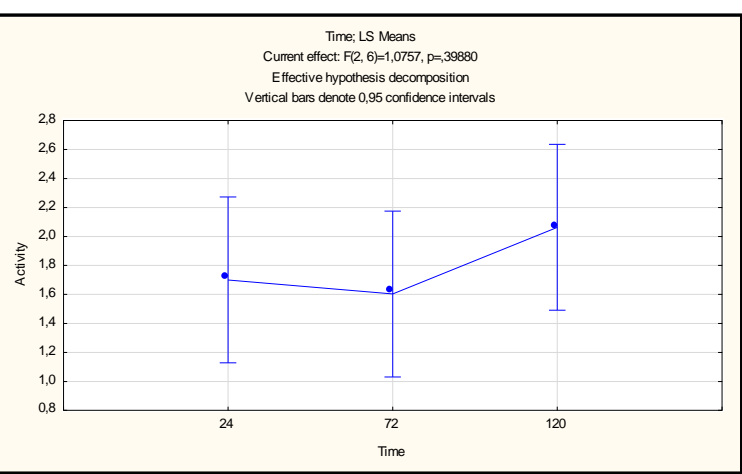

D

Figure 3. The relationship between the period of time and MDA content in leaves of the bromus treated with $S$. sclarea aqueous extract $(A)$, roots of the bromus treated with $S$. sclarea aqueous extract $(B)$, leaves of the bromus treated with $C$. menthifolium aqueous extract $(C)$, roots of the bromus treated with $C$. menthifolium aqueous extract $(D)$

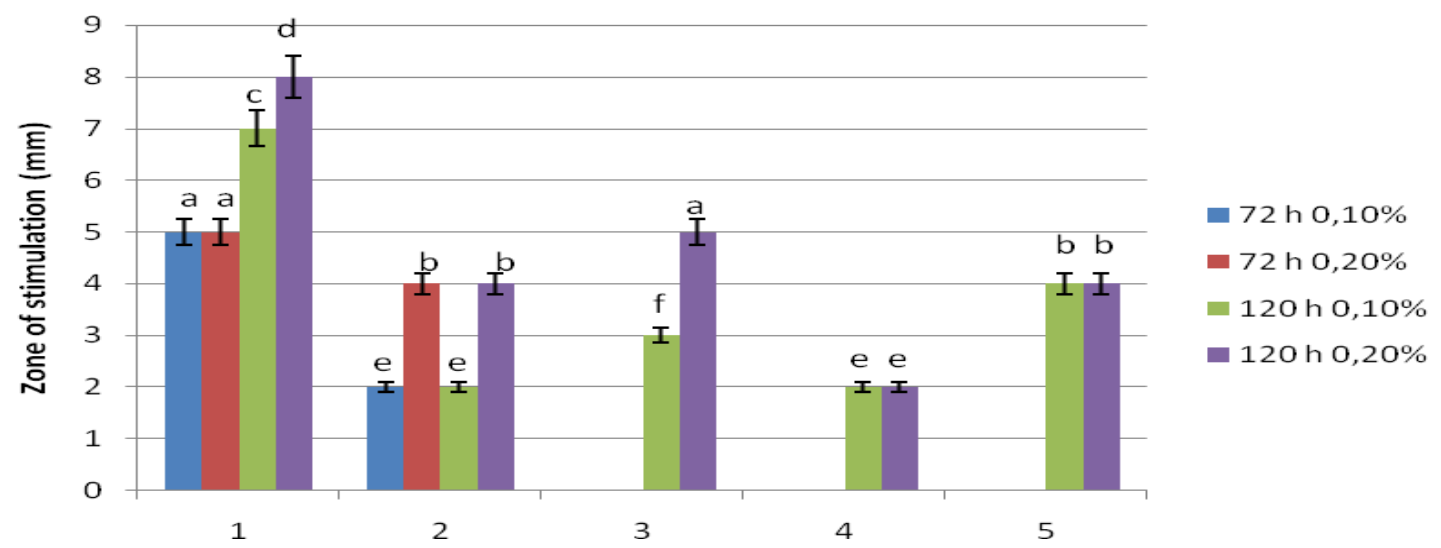

Figure 4. The stimulatory effect of the two concentrations (0.1 and $0.2 \%)$ of the S. sclarea aqueous extracts on the growth of test microorganism (1-Azotobacter isolate 1; 2-Azotobacter isolate 2; 3-Bacillus subtilis marker 44; 4-Rhizobium isolate $D_{1}, 5$-Bradyrhizobium japonicum isolate S511) 


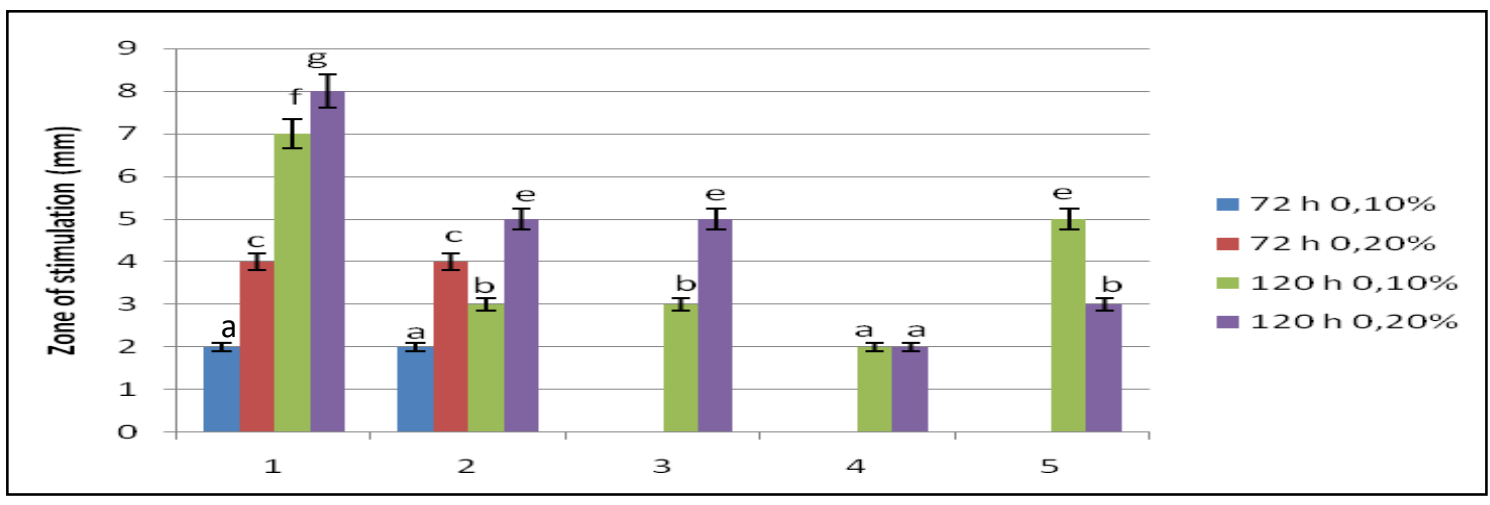

Figure 5. The stimulatory effect of the two concentrations (0.1 and $0.2 \%)$ of the C. menthifolium aqueous extracts on the growth of test microorganism (1-Azotobacter isolate 1; 2-Azotobacter isolate 2; 3-Bacillus subtilis marker 44; 4-Rhizobium isolate D1, 5-Bradyrhizobium japonicum isolate S511)

\section{Discussion}

The activity of antioxidant enzymes is frequently used as an indicator of oxidative stress in plants caused by pro-oxidants ( $\mathrm{Li}$ et al., 2013). For various plant species under oxidative stress, oxidative damage of cell membranes is observed. In this research, the phytotoxic effect of extracts was different between two examined plant tissues. Even though plant aqueous extracts affected the activity of the antioxidant enzymes in leaves and roots of the bromus seedlings, a significantly higher accumulation of MDA was detected only in leaves of bromus plants. The accumulation of MDA indicates that allelochemicals presented in plant extracts caused oxidative damage of membranes. No differences in MDA content in roots of bromus plants treated with extracts compared to untreated roots confirmed that leaves of bromus were more affected than roots. This is in accordance with the results reported in a study by Mahdavikia and Saharkhiz (2016) who reported that peppermint allelochemicals caused oxidative stress in the aerial parts of tomato seedlings. On the other hand, Chon et al. (2002) reported that even though phenolic compounds are involved in the inhibition of shoot growth, root length is a better indicator of phytotoxic effects of allelochemicals than shoot length. It is very important to know the mode of action of toxic compounds of plants. Non-protein amino acids produced by plants, such as meta-tyrosine ( $m$-Tyr), modify the activity of nonenzymatic antioxidants while cell membranes are not primary cellular targets (Andrzejczak et al., 2018). Contrarily, plant phenolic compounds, such as p-cymene and cinnamic acid increase lipid peroxidation in tested plants and stimulate total SOD activity (Zhang et al., 2012; Ding et al., 2007).

In this study, changes in enzymatic activity were the highest $72 \mathrm{~h}$ after the treatment. This was accompanied by the accumulation of MDA in bromus leaves. This observation could indicate that plant extracts exhibit a toxic effect in the first $72 \mathrm{~h}$. In the treatment with $C$. menthifolium aqueous extract both tested concentrations decreased the activity of antioxidant enzymes in roots of bromus plants. In spite of the increased activity of the enzymes, there were no significant changes in the lipid peroxidation intensity in roots of bromus between the plants from the control group and the treatments at the end of the experiment $(120 \mathrm{~h}$ after the treatment). This could indicate that the allelopathy-provoked stress was not strong enough and scavenging effects of antioxidant enzymes could still prevent an oxidative burst and the induction of lipid peroxidation. In the leaves and roots of black nightshade, due to the exposure to $C$. menthifolium aqueous extract, an increase in the lipid peroxidation process was 
observed (Šućur et al., 2017), which points to the different responses of species when facing allelochemicals. Chemical compounds produced by plants could be allelopathic agents with an inhibitory effect on plant growth. Phenolic compounds are identified as the most common allelochemicals produced by plants. Some phenolic compounds can either promote or inhibit plant growth according to their concentration ( $\mathrm{Li}$ et al., 2010). Nandakumar and Rangaswamy (1985) reported that some flavonoids had promotive effects on plant growth while in contrast to the flavonoids some phenolic acids suppressed plant growth and inhibited seed germinations. The allelopathic effects of plant extracts were investigated in a number of studies. For example, Islam et al. (2013) found that aqueous methanol extracts of Leucas aspera L. and Hyptis suaveolens L. possess strong allelopathic potential against barnyard grass. Franco et al. (2016) observed that Copaifera langsdorffii leaf extract had an inhibitory action on seed germination and root growth in sorghum. Furthermore, Thymus kotschyanus (Lamiaceae) exhibited dose-dependent allelopathic effects on Bromus tomentellus seed germination and seedling growth (Safari et al., 2010). Salvia officinalis (Lamiaceae) aqueous extract showed a strong inhibitory effect on Amaranthus retroflexus seed germination (Bajalan et al., 2013).

It is very important that herbicides or bioherbicides used for weed control have no inhibitory effect on the growth of beneficial mycorrhizal bacteria and fungi. Bacillus, Pseudomonas, Azotobacter and Rhizobium species are well known as plant growthpromoting rhizobacteria (PGPR). They play an important role in increasing soil fertility, promoting plant growth, and suppressing phytopathogens for the development of ecofriendly sustainable agriculture (Gupta et al., 2015). Plant growth-promoting fungi (PGPFs), such as species of the genera Trichoderma and Penicillium, also have the ability to stimulate the plant immune response upon enemy attack and growth promotion in crop plants (Jogaiah et al., 2013). It is a useful finding that the tested plant extracts showed a stimulatory effect on the growth of some beneficial bacteria.

\section{Conclusions}

Based on our current results, it can be concluded that S. sclarea and C. menthifolium aqueous extracts possess a negative effect against bromus, inducing oxidative stress accompanied by the induction of the lipid peroxidation process. C. menthifolium possesses a higher phytotoxic effect than $S$. sclarea whereas the accumulation of MDA was higher in leaves of bromus plants after the treatment with $C$. menthifolium aqueous extract compared to $S$. sclarea aqueous extract. In addition, negative effects are dependent on the plant tissues and the sensitivity of the plant is dependent on the concentration of applied extracts. Since the present investigation suggests that $S$. sclarea and $C$. menthifolium aqueous extracts possess a negative effect against the antioxidant system in weeds, and a stimulatory effect on the growth of some beneficial bacteria, it would be good to explore the aromatic plants in the development of natural pesticides.

\section{REFERENCES}

[1] Abd El-Gawad, A. M. (2016): Chemical constituents, antioxidant and potential allelopathic effect of the essential oil from the aerial parts of Cullen plicata. - Industrial Crops and Products 80: 36-41.

[2] Andrzejczak, O., Krasuska, U., Olechowicz, J., Staszek, P., Ciacka, K., Bogatek, R., Hebelstrup, K., Gniazdowska, A. (2018): Destabilization of ROS metabolism in tomato 
roots as a phytotoxic effect of meta-tyrosine. - Plant Physiology and Biochemistry 123: 369-377.

[3] Aquilanti, L., Favilli, F., Clemeti, F. (2004): Comparison of different strategies for isolation and preliminary identification of Azotobacter from soil samples. - Soil Biology and Biochemistry 36: 1475-1483.

[4] Azevedo Neto, D. A., Prisco, J. T., Enéas-Filiho, J., Braga De Abreu, C. E., Gomes-Filho, E. (2006): Effects of salt stress on antioxidative enzymes and lipid peroxidation in leaves and root of salt-tolerant and salt-sensitive maize genotypes. - Environmental and Experimental Botany 56: 87-94.

[5] Bajalan, I., Oregani, K. E., Moezi, A. A., Gholami, A. (2013): Allelopathic effects of aqueous extract from Salvia officinalis L. on seed germination of wheat and velvet flower. - Technical Journal of Engineering and Applied Sciences 3(6): 485-488.

[6] Bogatek, R., Gniazdowska, A., Zakrzewska, W., Oracz, K., Gawroski, S. W. (2006): Allelopathic effects of sunflower extracts on mustard seed germination and seedling growth. - Biologia Plantarum 50(1): 156-158.

[7] Céspedes, C. L., Salazar, J. R., Ariza-Castolo, A., Yamaguchi, L., Ávila, J. G., Aqueveque, P., Kubo, I., Alarcón, J. (2014): Biopesticides from plants: Calceolaria integrifolia s. 1. - Environmental Research 132: 391-406.

[8] Chon, S. U., Choi, S. K., Jung, S., Jang, H. G., Pyo, B. S., Kim, S. M. (2002): Effects of alfalfa leaf extracts and phenolic allelochemicals on early seedling growth and root morphology of alfalfa and barnyard grass. - Crop Protection 21: 1077-1082.

[9] Ding, J., Sun, Y., Xiao, C. L., Shi, K., Zhou, Y. H., Yu, J. Q. (2007): Physiological basis of different allelopathic reactions of cucumber and figleaf gourd plants to cinnamic acid. - Journal of Experimental Botany 58(13): 3765-3773.

[10] Farooq, M., Jabran, K., Cheema, Z. A., Wahid, A., Kadambot, H. M., Siddiquec, K. H. M. (2011): The role of allelopathy in agricultural pest management. - Pest Management Science 67: 493-506.

[11] Franco, D. M., Saldanha, L. L., Lima Neto, J. S., Dos Santos, J. C., Dokkedal, A. L., De Almeida, L. F. R. (2016): Seasonal variation in allelopathic potential of the leaves of Copaifera langsdorffii Desf. - Acta Botanica Brasilica 30(2), 157-165.

[12] Gonzalez Ponce, R., Zancada, C., Verdugo, M., Salas. L. (1996): Plant height as a factor in competition between black nightshade and two horticultural crops (tomato and pepper). - Journal of Horticultural Science 71: 453-460.

[13] Gupta, G., Singh Parihar, S., Kumar Ahirwar, N., Kumar Snehi, S., Singh, V. (2015): Plant growth promoting rhizobacteria (PGPR): Current and future prospects for development of sustainable agriculture. - Journal of Microbial \& Biochemical Technology 7(2): 096-102.

[14] Hermosa, R., Viterbo, A., Chet, I., Monte, E. (2012): Plant-beneficial effects of Trichoderma and of its genes. - Microbiology 158: 17-25.

[15] Hoagland, D. R., Arnon, D. I. (1950): The water-culture method for growing plants without soil. - Circular \& California Agricultural Experiment Station 347: 32.

[16] Holmgren, P. K., Holmgren. N. H. (2003): Additions to index herbariorum (Herbaria). Taxon 52: 385-389.

[17] Islam, A. K. M., Mominul, Kato-Noguchi, H. (2013): Allelopathic potential of five Labiatae plant species on barnyard grass ('Echinochloa crus-galli'). - Australian Journal of Crop Science 7(9): 1369-1374.

[18] Jabran, K., Mahajan, G., Sardana, V., Chauhan, B. S. (2015): Allelopathy for weed control in agricultural systems. - Crop Protection 72: 57-65.

[19] Jogaiah, S., Abdelrahman, M., Phan Tran, L. S., Shin-ichi, I. (2013): Characterization of rhizosphere fungi that mediate resistance in tomato against bacterial wilt disease. Journal of Experimental Botany 64(12): 3829-3842.

[20] Khalid, S., Ahmad, T., Shad, R. A. (2002): Use of allelopathy in agriculture. - Asian Journal of Plant Sciences 1(3): 292-297. 
[21] Kumar, R., Sharma, S. (2012): Effect of light and temperature on seed germination of important medicinal and aromatic plants in north western Himalayas. - International Journal of Medicinal and Aromatic Plants 2(3): 468-475.

[22] Li, Y., Hu, T., Zeng, F., Chen, H., Wu, X. (2013): Effects of Eucalyptus grandis Leaf Litter Decomposition on the Growth and Resistance Physiology Traits of Eremochloa ophiuroides. - Journal of Plant Studies 2(1): 158-165.

[23] Li, Z. H., Wang, Q., Ruan, X., Pan, C., Jiang, D. A. (2010): Phenolics and plant allelopathy. - Molecules 15: 8933-8952.

[24] Mahdavikia, F., Saharkhiz, M. J. (2016): Secondary metabolites of peppermint change the morphophysiological and biochemical characteristics of tomato. - Biocatalysis and Agricultural Biotechnology 7: 127-133.

[25] Mahmood, A., Mahmood, A., Mahmood, M. (2012): In vitro biological activities of most common medicinal plants of family Solanaceae. - World Applied Sciences Journal 17(8): $1026-1032$.

[26] Mandal, C., Ghosh, N., Adak, M. K., Dey, N. (2013): Interaction of polyamine on oxidative stress induced by exogenously applied hydrogen peroxide in Salvinia natans Linn. - Theoretical and Experimental Plant Physiology 25(3): 203-212.

[27] Mandal, S., Mitra, A., Mallick, N. (2008): Biochemical characterization of oxidative burst during interaction between Solanum lycopersicum and Fusarium oxysporum f. sp. lycopersici. - Physiological and Molecular Plant Pathology 72: 56-61.

[28] Meloni, D. A., Martinez, C. A. (2009): Glycinebetaine improves salt tolerance in vinal (Prosopis ruscifolia Griesbach) seedlings. - Brazilian Journal of Plant Physiology 21: 233-241.

[29] Morkunas, I., Gmerek, J. (2007): The possible involvement of peroxidase in defense of yellow lupine embryo axes against Fusarium oxysporum. - Journal of Plant Physiology 164: 185-194.

[30] Nandakumar, L., Rangaswamy, N. S. (1985): Effect of some flavonoids and phenolic acids o germination and rooting. - Journal of Experimental Botany 36: 1313-1319.

[31] Prabuseenivasan, S., Jayakumar, M., Ignacimuthu, S. (2006): In vitro antibacterial activity of some plant essential oils. - BMC Complementary and Alternative Medicine 6: $39-47$.

[32] Safari, H., Tavili, A., Saberi, M. (2010): Allelopathic effects of Thymus kotschyanus on seed germination and initial growth of Bromus tomentellus and Trifolium repens. Frontiers of Agriculture in China 4(4): 475-480.

[33] Sedmark, J., Grossberg, S. E. (1977): A rapid, sensitive and versatile assay for protein using Coomassie Brilliant Blue G250. - Analytical Biochemistry 79: 544-552.

[34] Šimonovičová, M., Tamás, L., Huttová, J., Široká, B., Mistrík, I. (2004): Activity of some enzymes in barley caryopses during imbibition in aluminium presence. - Plant, Soil and Environment 50(5): 189-195.

[35] Soares, C., De Sousa, A., Pinto, A., Azenha, M., Teixeira, J., Azevedo, R. A., Fidalgo, F. (2016): Effect of 24-epibrassinolide on ROS content, antioxidant system, lipid peroxidation and Ni uptake in Solanum nigrum L. under Ni stress. - Environmental and Experimental Botany 122: 115-125.

[36] Soltys, D., Krasuska, U., Bogatek, R., Gniazdowska, A. (2013): Allelochemicals as Bioherbicides - Present and Perspectives. - In; Andrew, J. P., Jessica, A. K. (eds.) Herbicides - Current Research and Case Studies in Use. IntechOpen, London. DOI: $10.5772 / 56185$.

[37] Spector, T. (1978): Refinement of the Coomassie blue method of protein quantitation. Analytical Biochemistry 86: 142-146.

[38] Šućur, J., Popović, A., Petrović, M., Bursić, V., Anačkov, G., Prvulović, D., Malenčić, Dj. 2017. Chemical composition of Clinopodium menthifolium aqueous extract and its influence on antioxidant system in black nightshade (Solanum nigrum) and pepper 
(Capsicum annuиm) seedlings and mortality rate of whitefly (Trialeurodes vaporariorum) adults. - Bulletin of the Chemical Society of Ethiopia 31(2): 211-222.

[39] Valls, J. S., Nacente, R. B., Coll, A. S. (1999): Scharlau Handbook of Microbiological Culture Meadia. - Scharlau Chemie, S. A., Barcelona, Spain.

[40] Zhang, F., Chen, F., Liu, W., Guo, J., Wan, F. (2012): $\rho$-Cymene inhibits growth and induces oxidative stress in rice seedling plants. - Weed Science 60: 564-570.

\section{APPENDIX}

\section{ANOVA tables}

Table A1. The effect of the C. menthifolium aqueous extract on MDA content (nmol/mg protein) in leaves of the bromus seedlings compared to control group

\begin{tabular}{|c|c|c|c|c|c|c|c|c|c|}
\hline \multirow[t]{2}{*}{ Cell No. } & \multicolumn{9}{|c|}{$\begin{array}{l}\text { Duncan test; variable Var2 (Spreadsheet } 1) \\
\text { Approximate Probabilities for Post Hoc Tests } \\
\text { Error: Between MS }=.03180, \mathrm{df}=18.000\end{array}$} \\
\hline & $\begin{array}{c}\{1\} \\
(3.8391) \\
\end{array}$ & $\begin{array}{c}\{2\} \\
(3.9842) \\
\end{array}$ & $\begin{array}{c}\{3\} \\
(4.2202) \\
\end{array}$ & $\begin{array}{c}\{4\} \\
(3.2673) \\
\end{array}$ & $\begin{array}{c}\{5\} \\
(4.7662) \\
\end{array}$ & $\begin{array}{c}\{6\} \\
(4.8370) \\
\end{array}$ & $\begin{array}{c}\{7\} \\
(5.4892) \\
\end{array}$ & $\begin{array}{c}\{8\} \\
(4.2402) \\
\end{array}$ & $\begin{array}{c}\{9\} \\
(5.4597) \\
\end{array}$ \\
\hline 1 & & 0.332331 & 0.022278 & 0.001135 & 0.000044 & 0.000035 & 0.000023 & 0.019607 & 0.000027 \\
\hline 2 & 0.332331 & & 0.122672 & 0.000214 & 0.000129 & 0.000063 & 0.000027 & 0.112208 & 0.000031 \\
\hline 3 & 0.022278 & 0.122672 & & 0.000067 & 0.002049 & 0.000892 & 0.000032 & 0.892058 & 0.000036 \\
\hline 4 & 0.001135 & 0.000214 & 0.000067 & & 0.000031 & 0.000027 & 0.000022 & 0.000040 & 0.000023 \\
\hline 5 & 0.000044 & 0.000129 & 0.002049 & 0.000031 & & 0.632518 & 0.000226 & 0.002145 & 0.000276 \\
\hline 6 & 0.000035 & 0.000063 & 0.000892 & 0.000027 & 0.632518 & & 0.000458 & 0.000983 & 0.000594 \\
\hline 7 & 0.000023 & 0.000027 & 0.000032 & 0.000022 & 0.000226 & 0.000458 & & 0.000036 & 0.841999 \\
\hline 8 & 0.019607 & 0.112208 & 0.892058 & 0.000040 & 0.002145 & 0.000983 & 0.000036 & & 0.000060 \\
\hline 9 & 0.000027 & 0.000031 & 0.000036 & 0.000023 & 0.000276 & 0.000594 & 0.841999 & 0.000060 & \\
\hline
\end{tabular}

*1-Control after $24 \mathrm{~h}, 2$-Treatment with $0.1 \%$ after $24 \mathrm{~h}, 3$-Treatment with $0.2 \%$ after $24 \mathrm{~h}$, 4-Control after $72 \mathrm{~h}, 5$-Treatment with $0.1 \%$ after $72 \mathrm{~h}, 6$-Treatment with $0.2 \%$ after $72 \mathrm{~h}, 7$-Control after $120 \mathrm{~h}, 8$ Treatment with $0.1 \%$ after $120 \mathrm{~h}, 9$-Treatment with $0.2 \%$ after $120 \mathrm{~h}$

Table A2. The effect of $C$. menthifolium aqueous extract on MDA content (nmol/mg protein) in roots of the bromus seedlings compared to control group

\begin{tabular}{|c|c|c|c|c|c|c|c|c|c|}
\hline \multirow[t]{2}{*}{ Cell No. } & \multicolumn{9}{|c|}{$\begin{array}{l}\text { Duncan test; variable Var2 (Spreadsheet1) } \\
\text { Approximate Probabilities for Post Hoc Tests } \\
\text { Error: Between MS }=.65187, \mathrm{df}=18.000\end{array}$} \\
\hline & $\begin{array}{c}\{1\} \\
(1.6616)\end{array}$ & $\begin{array}{c}\{2\} \\
(1.7245) \\
\end{array}$ & $\begin{array}{c}\{3\} \\
(1.7215) \\
\end{array}$ & $\begin{array}{c}\{4\} \\
(1.5287) \\
\end{array}$ & \begin{tabular}{|c|}
$5\}$ \\
$(1.7311)$ \\
\end{tabular} & $\begin{array}{c}\{6\} \\
(1.5624) \\
\end{array}$ & $\begin{array}{c}\{7\} \\
(2.8559) \\
\end{array}$ & $\begin{array}{c}\{8\} \\
(1.7963) \\
\end{array}$ & $\begin{array}{c}\{9\} \\
(1.5560)\end{array}$ \\
\hline 1 & & 0.929903 & 0.928749 & 0.856564 & 0.926590 & 0.882135 & 0.123705 & 0.858727 & 0.881857 \\
\hline 2 & 0.929903 & & 0.996542 & 0.796331 & 0.992170 & 0.825184 & 0.131357 & 0.919834 & 0.823156 \\
\hline 3 & 0.928749 & 0.996542 & & 0.797064 & 0.989849 & 0.822650 & 0.137598 & 0.921050 & 0.821561 \\
\hline 4 & 0.856564 & 0.796331 & 0.797064 & & 0.789782 & 0.963194 & 0.095978 & 0.724838 & 0.967538 \\
\hline 5 & 0.926590 & 0.992170 & 0.989849 & 0.789782 & & 0.822904 & 0.122637 & 0.922497 & 0.817360 \\
\hline 6 & 0.882135 & 0.825184 & 0.822650 & 0.963194 & 0.822904 & & 0.100134 & 0.758023 & 0.992459 \\
\hline 7 & 0.123705 & 0.131357 & 0.137598 & 0.095978 & 0.122637 & 0.100134 & & 0.125536 & 0.100811 \\
\hline 8 & 0.858727 & 0.919834 & 0.921050 & 0.724838 & 0.922497 & 0.758023 & 0.125536 & & 0.751855 \\
\hline 9 & 0.881857 & 0.823156 & 0.821561 & 0.967538 & 0.817360 & 0.992459 & 0.100811 & 0.751855 & \\
\hline
\end{tabular}

*1-Control after $24 \mathrm{~h}, 2$-Treatment with $0.1 \%$ after $24 \mathrm{~h}, 3$-Treatment with $0.2 \%$ after $24 \mathrm{~h}$, 4-Control after $72 \mathrm{~h}, 5$-Treatment with $0.1 \%$ after $72 \mathrm{~h}, 6$-Treatment with $0.2 \%$ after $72 \mathrm{~h}, 7$-Control after $120 \mathrm{~h}, 8$ Treatment with $0.1 \%$ after $120 \mathrm{~h}, 9$-Treatment with $0.2 \%$ after $120 \mathrm{~h}$ 
Table A3. The effect of the $S$. sclarea aqueous extract on MDA content (nmol/mg protein) in leaves of the bromus seedlings compared to control group

\begin{tabular}{|c|c|c|c|c|c|c|c|c|c|c|}
\hline \multirow[t]{2}{*}{ Cell No. } & \multicolumn{10}{|c|}{$\begin{array}{l}\text { Duncan test; variable Var2 (Spreadsheet1) } \\
\text { Approximate Probabilities for Post Hoc Tests } \\
\text { Error: Between MS }=.01914, \mathrm{df}=18.000\end{array}$} \\
\hline & Var1 & $\begin{array}{c}\{1\} \\
(3.8391)\end{array}$ & $\begin{array}{c}\{2\} \\
(4.8718)\end{array}$ & $\begin{array}{c}\{3\} \\
(3.7015)\end{array}$ & \begin{tabular}{c|}
$\{4\}$ \\
$(3.2673)$
\end{tabular} & $\begin{array}{c}\{5\} \\
(4.4442)\end{array}$ & $\begin{array}{c}\{6\} \\
(4.0087)\end{array}$ & $\begin{array}{c}\{7\} \\
(5.4892)\end{array}$ & $\begin{array}{c}\{8\} \\
(3.6074)\end{array}$ & $\begin{array}{c}\{9\} \\
(7.0484)\end{array}$ \\
\hline 1 & 1 & & 0.000060 & 0.238798 & 0.000194 & 0.000126 & 0.150785 & 0.000036 & 0.066617 & 0.000031 \\
\hline 2 & 2 & 0.000060 & & 0.000036 & 0.000027 & 0.001512 & 0.000075 & 0.000189 & 0.000031 & 0.000075 \\
\hline 3 & 3 & 0.238798 & 0.000036 & & 0.001674 & 0.000066 & 0.018073 & 0.000031 & 0.416198 & 0.000027 \\
\hline 4 & 4 & 0.000194 & 0.000027 & 0.001674 & & 0.000031 & 0.000041 & 0.000023 & 0.007667 & 0.000022 \\
\hline 5 & 5 & 0.000126 & 0.001512 & 0.000066 & 0.000031 & & 0.001302 & 0.000075 & 0.000036 & 0.000060 \\
\hline 6 & 6 & 0.150785 & 0.000075 & 0.018073 & 0.000041 & 0.001302 & & 0.000060 & 0.003754 & 0.000036 \\
\hline 7 & 7 & 0.000036 & 0.000189 & 0.000031 & 0.000023 & 0.000075 & 0.000060 & & 0.000027 & 0.000161 \\
\hline 8 & 8 & 0.066617 & 0.000031 & 0.416198 & 0.007667 & 0.000036 & 0.003754 & 0.000027 & & 0.000023 \\
\hline 9 & 9 & 0.000031 & 0.000075 & 0.000027 & 0.000022 & 0.000060 & 0.000036 & 0.000161 & 0.000023 & \\
\hline
\end{tabular}

*1-Control after $24 \mathrm{~h}, 2$-Treatment with $0.1 \%$ after $24 \mathrm{~h}, 3$-Treatment with $0.2 \%$ after $24 \mathrm{~h}$, 4-Control after $72 \mathrm{~h}, 5$-Treatment with $0.1 \%$ after $72 \mathrm{~h}, 6$-Treatment with $0.2 \%$ after $72 \mathrm{~h}, 7$-Control after $120 \mathrm{~h}, 8$ Treatment with $0.1 \%$ after $120 \mathrm{~h}, 9$-Treatment with $0.2 \%$ after $120 \mathrm{~h}$

Table A4. The effect of the S. sclarea aqueous extract on MDA content (nmol/mg protein) in roots of the bromus seedlings compared to control group

\begin{tabular}{|c|c|c|c|c|c|c|c|c|c|c|}
\hline \multirow{2}{*}{$\begin{array}{l}\text { Cell } \\
\text { No. }\end{array}$} & \multicolumn{10}{|c|}{$\begin{array}{l}\text { Duncan test; variable Var2 (Spreadsheet1) } \\
\text { Approximate Probabilities for Post Hoc Tests } \\
\text { Error: Between MS }=.64586, \text { df }=18.000\end{array}$} \\
\hline & Var1 & $\begin{array}{c}\{1\} \\
(1.6616) \\
\end{array}$ & $\begin{array}{c}\{2\} \\
(2.6440) \\
\end{array}$ & \begin{tabular}{c|c|}
$3\}$ \\
$(3.2268)$ \\
\end{tabular} & $\begin{array}{c}\{4\} \\
(1.5287) \\
\end{array}$ & $\begin{array}{c}\{5\} \\
(1.9357) \\
\end{array}$ & $\begin{array}{c}\{6\} \\
(2.3611) \\
\end{array}$ & $\begin{array}{c}\{7\} \\
(2.8559) \\
\end{array}$ & $\begin{array}{c}\{8\} \\
(2.4610) \\
\end{array}$ & $\begin{array}{c}\{9\} \\
(2.1663) \\
\end{array}$ \\
\hline 1 & 1 & & 0.199035 & 0.050623 & 0.841857 & 0.681258 & 0.341123 & 0.125384 & 0.286864 & 0.476813 \\
\hline 2 & 2 & 0.199035 & & 0.412212 & 0.150707 & 0.343830 & 0.688864 & 0.750672 & 0.783560 & 0.513248 \\
\hline 3 & 3 & 0.050623 & 0.412212 & & 0.036451 & 0.099244 & 0.249821 & 0.578961 & 0.298233 & 0.167079 \\
\hline 4 & 4 & 0.841857 & 0.150707 & 0.036451 & & 0.565382 & 0.267974 & 0.092955 & 0.221944 & 0.384671 \\
\hline 5 & 5 & 0.681258 & 0.343830 & 0.099244 & 0.565382 & & 0.548120 & 0.227765 & 0.472679 & 0.729488 \\
\hline 6 & 6 & 0.341123 & 0.688864 & 0.249821 & 0.267974 & 0.548120 & & 0.498447 & 0.880803 & 0.770136 \\
\hline 7 & 7 & 0.125384 & 0.750672 & 0.578961 & 0.092955 & 0.227765 & 0.498447 & & 0.576915 & 0.356484 \\
\hline 8 & 8 & 0.286864 & 0.783560 & 0.298233 & 0.221944 & 0.472679 & 0.880803 & 0.576915 & & 0.676742 \\
\hline 9 & 9 & 0.476813 & 0.513248 & 0.167079 & 0.384671 & 0.729488 & 0.770136 & 0.356484 & 0.676742 & \\
\hline
\end{tabular}

*1-Control after $24 \mathrm{~h}, 2$-Treatment with $0.1 \%$ after $24 \mathrm{~h}, 3$-Treatment with $0.2 \%$ after $24 \mathrm{~h}$, 4-Control after $72 \mathrm{~h}, 5$-Treatment with $0.1 \%$ after $72 \mathrm{~h}, 6$-Treatment with $0.2 \%$ after $72 \mathrm{~h}, 7$-Control after $120 \mathrm{~h}, 8$ Treatment with $0.1 \%$ after $120 \mathrm{~h}, 9$-Treatment with $0.2 \%$ after $120 \mathrm{~h}$

Table A5. The effect of the C. menthifolium aqueous extract on the activity of the guaiacol peroxidase (U/mg protein) in leaves of the bromus seedlings compared to control group

\begin{tabular}{|c|c|c|c|c|c|c|c|c|c|}
\hline \multirow{2}{*}{ Cell No. } & \multicolumn{9}{|c|}{$\begin{array}{l}\text { Duncan test; variable Var2 (Spreadsheet1) } \\
\text { Approximate Probabilities for Post Hoc Tests } \\
\text { Error: Between MS }=.00763, \mathrm{df}=18.000\end{array}$} \\
\hline & $\begin{array}{c}\{1\} \\
(.40147)\end{array}$ & $\begin{array}{c}\{2\} \\
(.56029) \\
\end{array}$ & $\begin{array}{c}\{3\} \\
(.40683)\end{array}$ & $\begin{array}{c}\{4\} \\
(.35696)\end{array}$ & $\begin{array}{c}\{5\} \\
(.66957)\end{array}$ & $\begin{array}{c}\{6\} \\
(.65905)\end{array}$ & $\begin{array}{c}\{7\} \\
(.51747)\end{array}$ & $\begin{array}{c}\{8\} \\
(.55683)\end{array}$ & $\begin{array}{c}\{9\} \\
(.41484) \\
\end{array}$ \\
\hline 1 & & 0.061888 & 0.941056 & 0.540447 & 0.003605 & 0.004561 & 0.151624 & 0.063844 & 0.861890 \\
\hline 2 & 0.061888 & & 0.066902 & 0.020727 & 0.163236 & 0.183090 & 0.577717 & 0.961933 & 0.075823 \\
\hline 3 & 0.941056 & 0.066902 & & 0.517307 & 0.003927 & 0.004905 & 0.158298 & 0.067697 & 0.911897 \\
\hline
\end{tabular}




\begin{tabular}{l|l|l|l|l|l|l|l|l|l|l|l|}
4 & 0.540447 & 0.020727 & 0.517307 & & 0.001064 & 0.001350 & 0.056118 & 0.021426 & 0.466550 \\
\hline 5 & 0.003605 & 0.163236 & 0.003927 & 0.001064 & & 0.884374 & 0.069174 & 0.162901 & 0.004559 \\
\hline 6 & 0.004561 & 0.183090 & 0.004905 & 0.001350 & 0.884374 & & 0.083409 & 0.190978 & 0.005603 \\
\hline 7 & 0.151624 & 0.577717 & 0.158298 & 0.056118 & 0.069174 & 0.083409 & & 0.587873 & 0.167332 \\
\hline 8 & 0.063844 & 0.961933 & 0.067697 & 0.021426 & 0.162901 & 0.190978 & 0.587873 & & 0.074311 \\
\hline 9 & 0.861890 & 0.075823 & 0.911897 & 0.466550 & 0.004559 & 0.005603 & 0.167332 & 0.074311 & \\
\hline
\end{tabular}

*1-Control after $24 \mathrm{~h}, 2$-Treatment with $0.1 \%$ after $24 \mathrm{~h}, 3$-Treatment with $0.2 \%$ after $24 \mathrm{~h}$, 4-Control after $72 \mathrm{~h}, 5$-Treatment with $0.1 \%$ after $72 \mathrm{~h}, 6$-Treatment with $0.2 \%$ after $72 \mathrm{~h}, 7$-Control after $120 \mathrm{~h}, 8$ Treatment with $0.1 \%$ after $120 \mathrm{~h}, 9$-Treatment with $0.2 \%$ after $120 \mathrm{~h}$

Table A6. The effect of the C. menthifolium aqueous extract on the activity of the guaiacol peroxidase (U/mg protein) in roots of the bromus seedlings compared to control group

\begin{tabular}{|c|c|c|c|c|c|c|c|c|c|}
\hline \multirow[t]{2}{*}{ Cell No. } & \multicolumn{9}{|c|}{$\begin{array}{l}\text { Duncan test; variable Var2 (Spreadsheet } 1) \\
\text { Approximate Probabilities for Post Hoc Tests } \\
\text { Error: Between MS }=.02164, \mathrm{df}=18.000\end{array}$} \\
\hline & $\begin{array}{c}\{1\} \\
(2.0964) \\
\end{array}$ & $\begin{array}{c}\{2\} \\
(1.0112) \\
\end{array}$ & $\begin{array}{c}\{3\} \\
(.62067) \\
\end{array}$ & $\begin{array}{c}\{4\} \\
(.56909)\end{array}$ & $\begin{array}{c}\{5\} \\
(.51857) \\
\end{array}$ & $\begin{array}{c}\{6\} \\
(.39514) \\
\end{array}$ & $\begin{array}{c}\{7\} \\
(1.0317)\end{array}$ & $\begin{array}{c}\{8\} \\
(.53162) \\
\end{array}$ & $\begin{array}{c}\{9\} \\
(.46335)\end{array}$ \\
\hline 1 & & 0.000075 & 0.000060 & 0.000036 & 0.000027 & 0.000022 & 0.000161 & 0.000031 & 0.000023 \\
\hline 2 & 0.000075 & & 0.004590 & 0.002373 & 0.001352 & 0.000210 & 0.866393 & 0.001482 & 0.000583 \\
\hline 3 & 0.000060 & 0.004590 & & 0.672836 & 0.446068 & 0.111363 & 0.004122 & 0.492737 & 0.253202 \\
\hline 4 & 0.000036 & 0.002373 & 0.672836 & & 0.696174 & 0.208052 & 0.001995 & 0.758857 & 0.430245 \\
\hline 5 & 0.000027 & 0.001352 & 0.446068 & 0.696174 & & 0.344026 & 0.001060 & 0.914771 & 0.651363 \\
\hline 6 & 0.000022 & 0.000210 & 0.111363 & 0.208052 & 0.344026 & & 0.000162 & 0.310922 & 0.577319 \\
\hline 7 & 0.000161 & 0.866393 & 0.004122 & 0.001995 & 0.001060 & 0.000162 & & 0.001187 & 0.000454 \\
\hline 8 & 0.000031 & 0.001482 & 0.492737 & 0.758857 & 0.914771 & 0.310922 & 0.001187 & & 0.598110 \\
\hline 9 & 0.000023 & 0.000583 & 0.253202 & 0.430245 & 0.651363 & 0.577319 & 0.000454 & 0.598110 & \\
\hline
\end{tabular}

*1-Control after $24 \mathrm{~h}, 2$-Treatment with $0.1 \%$ after $24 \mathrm{~h}, 3$-Treatment with $0.2 \%$ after $24 \mathrm{~h}$, 4-Control after $72 \mathrm{~h}, 5$-Treatment with $0.1 \%$ after $72 \mathrm{~h}, 6$-Treatment with $0.2 \%$ after $72 \mathrm{~h}, 7$-Control after $120 \mathrm{~h}, 8$ Treatment with $0.1 \%$ after $120 \mathrm{~h}, 9$-Treatment with $0.2 \%$ after $120 \mathrm{~h}$

Table A7. The effect of the S. sclarea aqueous extract on the activity of the guaiacol peroxidase (U/mg protein) in leaves of the bromus seedlings compared to control group

\begin{tabular}{|c|c|c|c|c|c|c|c|c|c|}
\hline \multirow[t]{2}{*}{ Cell No. } & \multicolumn{9}{|c|}{$\begin{array}{l}\text { Duncan test; variable Var2 (Spreadsheet1) } \\
\text { Approximate Probabilities for Post Hoc Tests } \\
\text { Error: Between MS }=.00169, \mathrm{df}=18.000\end{array}$} \\
\hline & $\begin{array}{c}\{1\} \\
(.40147) \\
\end{array}$ & $\begin{array}{c}\{2\} \\
(.47785) \\
\end{array}$ & $\begin{array}{c}\{3\} \\
(.34468) \\
\end{array}$ & $\begin{array}{c}\{4\} \\
(.35696) \\
\end{array}$ & $\begin{array}{c}\{5\} \\
(.22902) \\
\end{array}$ & $\begin{array}{c}\{6\} \\
(.54691) \\
\end{array}$ & $\begin{array}{c}\{7\} \\
(.51747) \\
\end{array}$ & $\begin{array}{c}\{8\} \\
(.37484) \\
\end{array}$ & $\begin{array}{c}\{9\} \\
(.50578) \\
\end{array}$ \\
\hline 1 & & 0.035627 & 0.136981 & 0.225625 & 0.000177 & 0.000842 & 0.004638 & 0.438493 & 0.008104 \\
\hline 2 & 0.035627 & & 0.001810 & 0.003411 & 0.000032 & 0.073814 & 0.279081 & 0.008792 & 0.416899 \\
\hline 3 & 0.136981 & 0.001810 & & 0.718996 & 0.003070 & 0.000053 & 0.000204 & 0.407277 & 0.000364 \\
\hline 4 & 0.225625 & 0.003411 & 0.718996 & & 0.001806 & 0.000085 & 0.000377 & 0.601344 & 0.000685 \\
\hline 5 & 0.000177 & 0.000032 & 0.003070 & 0.001806 & & 0.000022 & 0.000023 & 0.000721 & 0.000028 \\
\hline 6 & 0.000842 & 0.073814 & 0.000053 & 0.000085 & 0.000022 & & 0.392736 & 0.000196 & 0.261713 \\
\hline 7 & 0.004638 & 0.279081 & 0.000204 & 0.000377 & 0.000023 & 0.392736 & & 0.001000 & 0.732088 \\
\hline 8 & 0.438493 & 0.008792 & 0.407277 & 0.601344 & 0.000721 & 0.000196 & 0.001000 & & 0.001811 \\
\hline 9 & 0.008104 & 0.416899 & 0.000364 & 0.000685 & 0.000028 & 0.261713 & 0.732088 & 0.001811 & \\
\hline
\end{tabular}

*1-Control after $24 \mathrm{~h}, 2$-Treatment with $0.1 \%$ after $24 \mathrm{~h}, 3$-Treatment with $0.2 \%$ after $24 \mathrm{~h}$, 4-Control after $72 \mathrm{~h}, 5$-Treatment with $0.1 \%$ after $72 \mathrm{~h}, 6$-Treatment with $0.2 \%$ after $72 \mathrm{~h}, 7$-Control after $120 \mathrm{~h}, 8$ Treatment with $0.1 \%$ after $120 \mathrm{~h}, 9$-Treatment with $0.2 \%$ after $120 \mathrm{~h}$ 
Table A8. The effect of the S. sclarea aqueous extract on the activity of the guaiacol peroxidase (U/mg protein) in roots of the bromus seedlings compared to control group

\begin{tabular}{|c|c|c|c|c|c|c|c|c|c|}
\hline \multirow[t]{2}{*}{ Cell No. } & \multicolumn{9}{|c|}{$\begin{array}{l}\text { Duncan test; variable Var2 (Spreadsheet } 1) \\
\text { Approximate Probabilities for Post Hoc Tests } \\
\text { Error: Between MS }=.06693, \mathrm{df}=18.000\end{array}$} \\
\hline & $\begin{array}{c}\{1\} \\
(2.0964)\end{array}$ & $\begin{array}{c}\{2\} \\
(1.7118)\end{array}$ & $\begin{array}{c}\{3\} \\
(2.5328) \\
\end{array}$ & $\begin{array}{c}\{4\} \\
(.56909)\end{array}$ & $\begin{array}{c}\{5\} \\
(.59976)\end{array}$ & $\begin{array}{c}\{6\} \\
(2.0422)\end{array}$ & $\begin{array}{c}\{7\} \\
(1.0317)\end{array}$ & $\begin{array}{c}\{8\} \\
(3.5923)\end{array}$ & $\begin{array}{c}\{9\} \\
(1.6836) \\
\end{array}$ \\
\hline 1 & & 0.100717 & 0.053662 & 0.000029 & 0.000033 & 0.800615 & 0.000207 & 0.000076 & 0.088101 \\
\hline 2 & 0.100717 & & 0.001851 & 0.000113 & 0.000147 & 0.135309 & 0.006351 & 0.000036 & 0.895507 \\
\hline 3 & 0.053662 & 0.001851 & & 0.000023 & 0.000027 & 0.039904 & 0.000033 & 0.000240 & 0.001602 \\
\hline 4 & 0.000029 & 0.000113 & 0.000023 & & 0.886289 & 0.000034 & 0.051416 & 0.000022 & 0.000145 \\
\hline 5 & 0.000033 & 0.000147 & 0.000027 & 0.886289 & & 0.000038 & 0.055913 & 0.000023 & 0.000161 \\
\hline 6 & 0.800615 & 0.135309 & 0.039904 & 0.000034 & 0.000038 & & 0.000308 & 0.000060 & 0.124405 \\
\hline 7 & 0.000207 & 0.006351 & 0.000033 & 0.051416 & 0.055913 & 0.000308 & & 0.000027 & 0.006543 \\
\hline 8 & 0.000076 & 0.000036 & 0.000240 & 0.000022 & 0.000023 & 0.000060 & 0.000027 & & 0.000031 \\
\hline 9 & 0.088101 & 0.895507 & 0.001602 & 0.000145 & 0.000161 & 0.124405 & 0.006543 & 0.000031 & \\
\hline
\end{tabular}

*1-Control after $24 \mathrm{~h}, 2$-Treatment with $0.1 \%$ after $24 \mathrm{~h}, 3$-Treatment with $0.2 \%$ after $24 \mathrm{~h}$, 4-Control after $72 \mathrm{~h}, 5$-Treatment with $0.1 \%$ after $72 \mathrm{~h}, 6$-Treatment with $0.2 \%$ after $72 \mathrm{~h}, 7$-Control after $120 \mathrm{~h}, 8$ Treatment with $0.1 \%$ after $120 \mathrm{~h}, 9$-Treatment with $0.2 \%$ after $120 \mathrm{~h}$

Table A9. The effect of the C. menthifolium aqueous extract on the activity of the pyrogallol peroxidase (U/mg protein) in leaves of the bromus seedlings compared to control group

\begin{tabular}{|c|c|c|c|c|c|c|c|c|c|}
\hline \multirow{2}{*}{ Cell No. } & \multicolumn{9}{|c|}{$\begin{array}{l}\text { Duncan test; variable Var2 (Spreadsheet1) } \\
\text { Approximate Probabilities for Post Hoc Tests } \\
\text { Error: Between MS }=.00186, \mathrm{df}=18.000\end{array}$} \\
\hline & $\begin{array}{c}\{1\} \\
(.38770)\end{array}$ & $\begin{array}{c}\{2\} \\
(.41418)\end{array}$ & $\begin{array}{c}\{3\} \\
(.29249)\end{array}$ & $\begin{array}{c}\{4\} \\
(.35137)\end{array}$ & $\begin{array}{c}\{5\} \\
(.43739)\end{array}$ & $\begin{array}{c}\{6\} \\
(.40171)\end{array}$ & $\begin{array}{c}\{7\} \\
(.34141)\end{array}$ & $\begin{array}{c}\{8\} \\
(.33818)\end{array}$ & $\begin{array}{c}\{9\} \\
(.43094)\end{array}$ \\
\hline 1 & & 0.486523 & 0.024042 & 0.315864 & 0.219410 & 0.695532 & 0.228930 & 0.212466 & 0.274280 \\
\hline 2 & 0.486523 & & 0.006272 & 0.117495 & 0.541449 & 0.727435 & 0.077614 & 0.069720 & 0.639831 \\
\hline 3 & 0.024042 & 0.006272 & & 0.141013 & 0.001849 & 0.011904 & 0.204510 & 0.210874 & 0.002532 \\
\hline 4 & 0.315864 & 0.117495 & 0.141013 & & 0.042101 & 0.192091 & 0.780603 & 0.727966 & 0.055206 \\
\hline 5 & 0.219410 & 0.541449 & 0.001849 & 0.042101 & & 0.364965 & 0.026290 & 0.023165 & 0.856957 \\
\hline 6 & 0.695532 & 0.727435 & 0.011904 & 0.192091 & 0.364965 & & 0.132082 & 0.120389 & 0.442851 \\
\hline 7 & 0.228930 & 0.077614 & 0.204510 & 0.780603 & 0.026290 & 0.132082 & & 0.928127 & 0.035046 \\
\hline 8 & 0.212466 & 0.069720 & 0.210874 & 0.727966 & 0.023165 & 0.120389 & 0.928127 & & 0.031161 \\
\hline 9 & 0.274280 & 0.639831 & 0.002532 & 0.055206 & 0.856957 & 0.442851 & 0.035046 & 0.031161 & \\
\hline
\end{tabular}

*1-Control after $24 \mathrm{~h}, 2$-Treatment with $0.1 \%$ after $24 \mathrm{~h}, 3$-Treatment with $0.2 \%$ after $24 \mathrm{~h}$, 4-Control after $72 \mathrm{~h}, 5$-Treatment with $0.1 \%$ after $72 \mathrm{~h}, 6$-Treatment with $0.2 \%$ after $72 \mathrm{~h}, 7$-Control after $120 \mathrm{~h}, 8$ Treatment with $0.1 \%$ after $120 \mathrm{~h}, 9$-Treatment with $0.2 \%$ after $120 \mathrm{~h}$

Table A10. The effect of the $C$. menthifolium aqueous extract on the activity of the pyrogallol peroxidase (U/mg protein) in roots of the bromus seedlings compared to control group

\begin{tabular}{c|c|c|c|c|c|c|c|c|c}
\hline & \multicolumn{8}{|c}{ Duncan test; variable Var2 (Spreadsheet1) } \\
Approximate Probabilities for Post Hoc Tests \\
Cell No.
\end{tabular}




\begin{tabular}{l|l|l|l|l|l|l|l|l|l|l}
3 & 0.000075 & 0.649203 & & 0.000127 & 0.004236 & 0.000072 & 0.388464 & 0.000061 & 0.000028 \\
\hline 4 & 0.000031 & 0.000063 & 0.000127 & & 0.063602 & 0.724697 & 0.000438 & 0.642921 & 0.026336 \\
\hline 5 & 0.000036 & 0.001910 & 0.004236 & 0.063602 & & 0.038900 & 0.021330 & 0.033797 & 0.000500 \\
\hline 6 & 0.000027 & 0.000046 & 0.000072 & 0.724697 & 0.038900 & & 0.000269 & 0.889048 & 0.046060 \\
\hline 7 & 0.000060 & 0.218177 & 0.388464 & 0.000438 & 0.021330 & 0.000269 & & 0.000222 & 0.000033 \\
\hline 8 & 0.000023 & 0.000039 & 0.000061 & 0.642921 & 0.033797 & 0.889048 & 0.000222 & & 0.049609 \\
\hline 9 & 0.000022 & 0.000023 & 0.000028 & 0.026336 & 0.000500 & 0.046060 & 0.000033 & 0.049609 & \\
\hline
\end{tabular}

*1-Control after $24 \mathrm{~h}, 2$-Treatment with $0.1 \%$ after $24 \mathrm{~h}, 3$-Treatment with $0.2 \%$ after $24 \mathrm{~h}, 4$-Control after $72 \mathrm{~h}, 5$-Treatment with $0.1 \%$ after $72 \mathrm{~h}, 6$-Treatment with $0.2 \%$ after $72 \mathrm{~h}, 7$-Control after $120 \mathrm{~h}, 8$ Treatment with $0.1 \%$ after $120 \mathrm{~h}, 9$-Treatment with $0.2 \%$ after $120 \mathrm{~h}$

Table A11. The effect of the S. sclarea aqueous extract on the activity of the pyrogallol peroxidase (U/mg protein) in leaves of the bromus seedlings compared to control group

\begin{tabular}{|c|c|c|c|c|c|c|c|c|c|}
\hline \multirow[t]{2}{*}{ Cell No. } & \multicolumn{9}{|c|}{$\begin{array}{l}\text { Duncan test; variable Var2 (Spreadsheet } 1) \\
\text { Approximate Probabilities for Post Hoc Tests } \\
\text { Error: Between MS }=.00234, \mathrm{df}=18.000\end{array}$} \\
\hline & $\begin{array}{c}\{1\} \\
(.38770)\end{array}$ & $\begin{array}{c}\{2\} \\
(.33563)\end{array}$ & $\begin{array}{c}\{3\} \\
(.36302)\end{array}$ & $\begin{array}{c}\{4\} \\
(.35137)\end{array}$ & $\begin{array}{c}\{5\} \\
(.24814)\end{array}$ & $\begin{array}{c}\{6\} \\
(.32123)\end{array}$ & $\begin{array}{c}\{7\} \\
(.34141)\end{array}$ & $\begin{array}{c}\{8\} \\
(.33509)\end{array}$ & $\begin{array}{c}\{9\} \\
(.34087)\end{array}$ \\
\hline 1 & & 0.255383 & 0.539710 & 0.395622 & 0.005999 & 0.156661 & 0.295902 & 0.254290 & 0.299232 \\
\hline 2 & 0.255383 & & 0.540064 & 0.719503 & 0.055140 & 0.734634 & 0.892068 & 0.989366 & 0.895871 \\
\hline 3 & 0.539710 & 0.540064 & & 0.771357 & 0.019433 & 0.361510 & 0.611535 & 0.536521 & 0.613689 \\
\hline 4 & 0.395622 & 0.719503 & 0.771357 & & 0.032279 & 0.505083 & 0.803740 & 0.715576 & 0.804920 \\
\hline 5 & 0.005999 & 0.055140 & 0.019433 & 0.032279 & & 0.080667 & 0.048649 & 0.050154 & 0.046933 \\
\hline 6 & 0.156661 & 0.734634 & 0.361510 & 0.505083 & 0.080667 & & 0.651061 & 0.729571 & 0.654013 \\
\hline 7 & 0.295902 & 0.892068 & 0.611535 & 0.803740 & 0.048649 & 0.651061 & & 0.886979 & 0.989458 \\
\hline 8 & 0.254290 & 0.989366 & 0.536521 & 0.715576 & 0.050154 & 0.729571 & 0.886979 & & 0.891982 \\
\hline 9 & 0.299232 & 0.895871 & 0.613689 & 0.804920 & 0.046933 & 0.654013 & 0.989458 & 0.891982 & \\
\hline
\end{tabular}

*1-Control after $24 \mathrm{~h}, 2$-Treatment with $0.1 \%$ after $24 \mathrm{~h}, 3$-Treatment with $0.2 \%$ after $24 \mathrm{~h}$, 4-Control after $72 \mathrm{~h}, 5$-Treatment with $0.1 \%$ after $72 \mathrm{~h}, 6$-Treatment with $0.2 \%$ after $72 \mathrm{~h}, 7$-Control after $120 \mathrm{~h}, 8$ Treatment with $0.1 \%$ after $120 \mathrm{~h}, 9$-Treatment with $0.2 \%$ after $120 \mathrm{~h}$

Table A12. The effect of the S. sclarea aqueous extract on the activity of the pyrogallol peroxidase (U/mg protein) in roots of the bromus seedlings compared to control group

\begin{tabular}{|c|c|c|c|c|c|c|c|c|c|}
\hline \multirow[t]{2}{*}{ Cell No. } & \multicolumn{9}{|c|}{$\begin{array}{l}\text { Duncan test; variable Var2 (Spreadsheet1) } \\
\text { Approximate Probabilities for Post Hoc Tests } \\
\text { Error: Between MS }=.07228, \mathrm{df}=18.000\end{array}$} \\
\hline & $\begin{array}{c}\{1\} \\
(1.7518)\end{array}$ & $\begin{array}{c}\{2\} \\
(1.2701)\end{array}$ & $\begin{array}{c}\{3\} \\
(1.9958)\end{array}$ & $\begin{array}{c}\{4\} \\
(.53660)\end{array}$ & $\begin{array}{c}\{5\} \\
(.47918)\end{array}$ & $\begin{array}{c}\{6\} \\
(1.0592)\end{array}$ & $\begin{array}{c}\{7\} \\
(.94740) \\
\end{array}$ & $\begin{array}{c}\{8\} \\
(2.0475)\end{array}$ & $\begin{array}{c}\{9\} \\
(.97299)\end{array}$ \\
\hline 1 & & 0.041693 & 0.281264 & 0.000097 & 0.000069 & 0.007276 & 0.003396 & 0.218168 & 0.003789 \\
\hline 2 & 0.041693 & & 0.005292 & 0.006664 & 0.004281 & 0.349384 & 0.193207 & 0.003843 & 0.215977 \\
\hline 3 & 0.281264 & 0.005292 & & 0.000033 & 0.000029 & 0.000837 & 0.000378 & 0.816350 & 0.000428 \\
\hline 4 & 0.000097 & 0.006664 & 0.000033 & & 0.796712 & 0.040651 & 0.077774 & 0.000029 & 0.074785 \\
\hline 5 & 0.000069 & 0.004281 & 0.000029 & 0.796712 & & 0.027111 & 0.057242 & 0.000025 & 0.051922 \\
\hline 6 & 0.007276 & 0.349384 & 0.000837 & 0.040651 & 0.027111 & & 0.636617 & 0.000590 & 0.699390 \\
\hline 7 & 0.003396 & 0.193207 & 0.000378 & 0.077774 & 0.057242 & 0.636617 & & 0.000261 & 0.908605 \\
\hline 8 & 0.218168 & 0.003843 & 0.816350 & 0.000029 & 0.000025 & 0.000590 & 0.000261 & & 0.000299 \\
\hline 9 & 0.003789 & 0.215977 & 0.000428 & 0.074785 & 0.051922 & 0.699390 & 0.908605 & 0.000299 & \\
\hline
\end{tabular}

*1-Control after $24 \mathrm{~h}, 2$-Treatment with $0.1 \%$ after $24 \mathrm{~h}, 3$-Treatment with $0.2 \%$ after $24 \mathrm{~h}$, 4-Control after $72 \mathrm{~h}, 5$-Treatment with $0.1 \%$ after $72 \mathrm{~h}, 6$-Treatment with $0.2 \%$ after $72 \mathrm{~h}, 7$-Control after $120 \mathrm{~h}, 8$ Treatment with $0.1 \%$ after $120 \mathrm{~h}, 9$-Treatment with $0.2 \%$ after 120 